\title{
Quantum Leap from Gold and Silver to Aluminum Nanoplasmonics for Enhanced Biomedical Applications
}

\author{
Sharad Ambardar ${ }^{1}$, Dang Nguyen ${ }^{1}$, Grace Binder ${ }^{2}$, Zachary W. Withers ${ }^{3}$ and \\ Dmitri V. Voronine $1,3, *$ (D) \\ 1 Department of Medical Engineering, University of South Florida, Tampa, FL 33620, USA; \\ sharad@mail.usf.edu (S.A.); dang3@mail.usf.edu (D.N.) \\ 2 Department of Chemistry, University of South Florida, Tampa, FL 33620, USA; gbinder@usf.edu \\ 3 Department of Physics, University of South Florida, Tampa, FL 33620, USA; zwithers@mail.usf.edu \\ * Correspondence: voronine@usf.edu
}

Received: 30 April 2020; Accepted: 16 June 2020; Published: 19 June 2020

\begin{abstract}
Nanotechnology has been used in many biosensing and medical applications, in the form of noble metal (gold and silver) nanoparticles and nanostructured substrates. However, the translational clinical and industrial applications still need improvements of the efficiency, selectivity, cost, toxicity, reproducibility, and morphological control at the nanoscale level. In this review, we highlight the recent progress that has been made in the replacement of expensive gold and silver metals with the less expensive aluminum. In addition to low cost, other advantages of the aluminum plasmonic nanostructures include a broad spectral range from deep UV to near IR, providing additional signal enhancement and treatment mechanisms. New synergistic treatments of bacterial infections, cancer, and coronaviruses are envisioned. Coupling with gain media and quantum optical effects improve the performance of the aluminum nanostructures beyond gold and silver.
\end{abstract}

Keywords: aluminum plasmonics; UV; photothermal therapy; hot electron; cancer; bacteria

\section{Introduction}

The combination of several treatment mechanisms enabled by aluminum (Al) nanostructures (NSs) may be used to develop new medical devices for sensor-guided therapy, food security, and environmental applications. For example, plasmonic ultraviolet (UV) response and enhanced sensing properties of Al NSs such as Al nanoparticles (NPs) and metamaterial substrates could be used for point-of-care medical treatment. To develop efficient devices, it is important to better understand the treatment mechanisms and to optimize control strategies. The goal is to perform biomolecular detection with high sensitivity in real time and to develop cheaper point-of-care treatment. This review is focused on highlighting the biomedical applications of several technologies that could be improved by using aluminum nanoplasmonics.

Classical nanoplasmonics with gold $(\mathrm{Au})$ and silver $(\mathrm{Ag}) \mathrm{NSs}$ is based on the local electromagnetic near-field enhancement, with surface plasmon resonance (SPR), which depends on the size, shape, and material properties of the NSs. Au and Ag plasmonic NSs have SPRs in the visible and near infrared spectral range. On the other hand, Al NSs have an extended spectral range into deep UV, which enables a broad variety of applications. Under an ambient environment, the surface of aluminum is covered with a thin layer of $\mathrm{Al}_{2} \mathrm{O}_{3}$. However, the thickness of the $\mathrm{Al}_{2} \mathrm{O}_{3}$ layer may be used for tuning the plasmonic response of $\mathrm{Al} \mathrm{NSs} \mathrm{in} \mathrm{a} \mathrm{wide} \mathrm{spectral} \mathrm{range} \mathrm{[1].}$

In this review, we first give an overview of aluminum plasmonics in Section 2, including nanostructure fabrication (Section 2.1) and treatment mechanisms (Section 2.2). Then we review 
the biosensing applications of Au and Ag plasmonic NSs with several examples of spectroscopic signals enhanced by Al NSs (Section 3.1). We discuss plasmonic biomedical applications in Section 3.2, with the treatments of cancer (Section 3.2.1) and bacteria (Section 3.2.2), highlighting the advantages and limitations of $\mathrm{Au}$ and $\mathrm{Ag}$, and the promising applications of $\mathrm{Al}$ plasmonics. We discuss strategies to improve the performance of Al NSs in Section 4, including alloys/composites (Section 4.1), chemical enhancement (Section 4.2), quantum effects (Section 4.3), future translational applications (Section 5), and we conclude with a summary in Section 6.

\section{Aluminum Plasmonics}

\subsection{Nanostructure Fabrication}

Only a few studies of biological systems with nanofabricated Al plasmonic substrates have been performed. Variable shapes of Al NSs may be used to optimize the near-field enhancement and spectral response. Figure 1 shows that the optical response of Al NPs may be tunable over a broad spectral range by varying the NP size [1]. Recently, it was also shown that other substrate parameters may be varied such as the shape, inter-particle distance, and the refractive index of the substrate to control the Al plasmonic response [2-13]. Broad tunability of the plasmonic response has been achieved using periodically designed Al NP substrates on a stretchable support [14]. Plasmonic Al nanoantennas have been designed with controllable localized near-field hot spots [15-20].
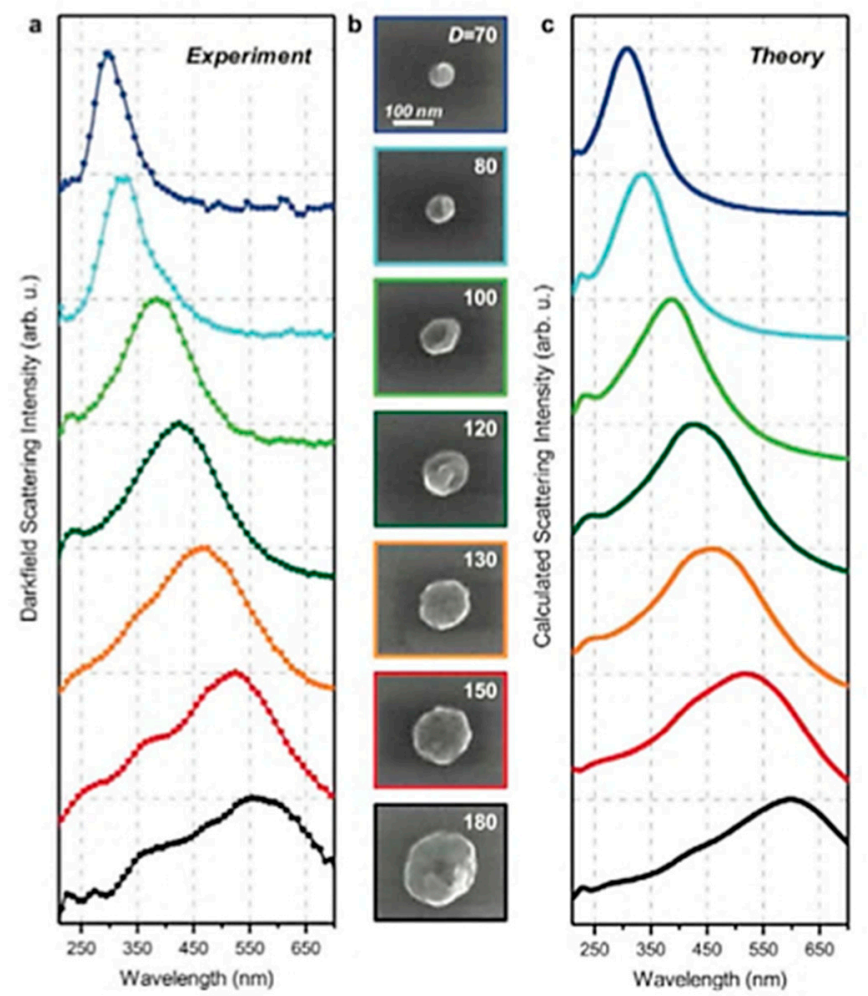

Figure 1. Broadband tunable aluminum plasmonics: (a) Experimental spectra; (b) electron microscope images; and (c) simulated spectra of Al nanoparticles (NPs) with varying sizes. (Adapted from Knight et al. [1]).

Al NP colloidal synthetic methods provide possibilities for facile scalable manufacturing [21-23]. Considering stability and agglomeration issues, Al NPs can be synthesized via surface passivating agents for protection and stabilization. Templates can be used for large-scale synthesis of Al NPs via catalytic decomposition [22,24]. Passivation agents play an essential role in stabilizing Al NPs as well as protecting them from further surface oxidation. Synthesis of highly regular, faceted $\mathrm{Al}$ nanocrystals 
with controllable nanocrystal diameters and shapes, including nanorods and nanocubes, has been reported [25-27]. Al nanocrystals were also decorated with size-tunable transition-metal nanoparticles to control UV absorption and scattering [28].

Several methods have utilized inexpensive Al foil for Al NS fabrication [29-31]. We recently developed a method of ultrasonic synthesis of irregular disk-shaped Al NPs from commercial $\mathrm{Al}$ wrapping foil, and used these Al NPs to affect bacterial inactivation efficiency (Figure 2) [29]. Another sonophysical method of Al NS preparation from the commercial Al foil showed bacterial toxicity of Al NS smaller than $25 \mu \mathrm{m}$ [30]. Nanotexturing of commercial Al foils by anodization has shown another promising route to plasmonic substrate fabrication [31].
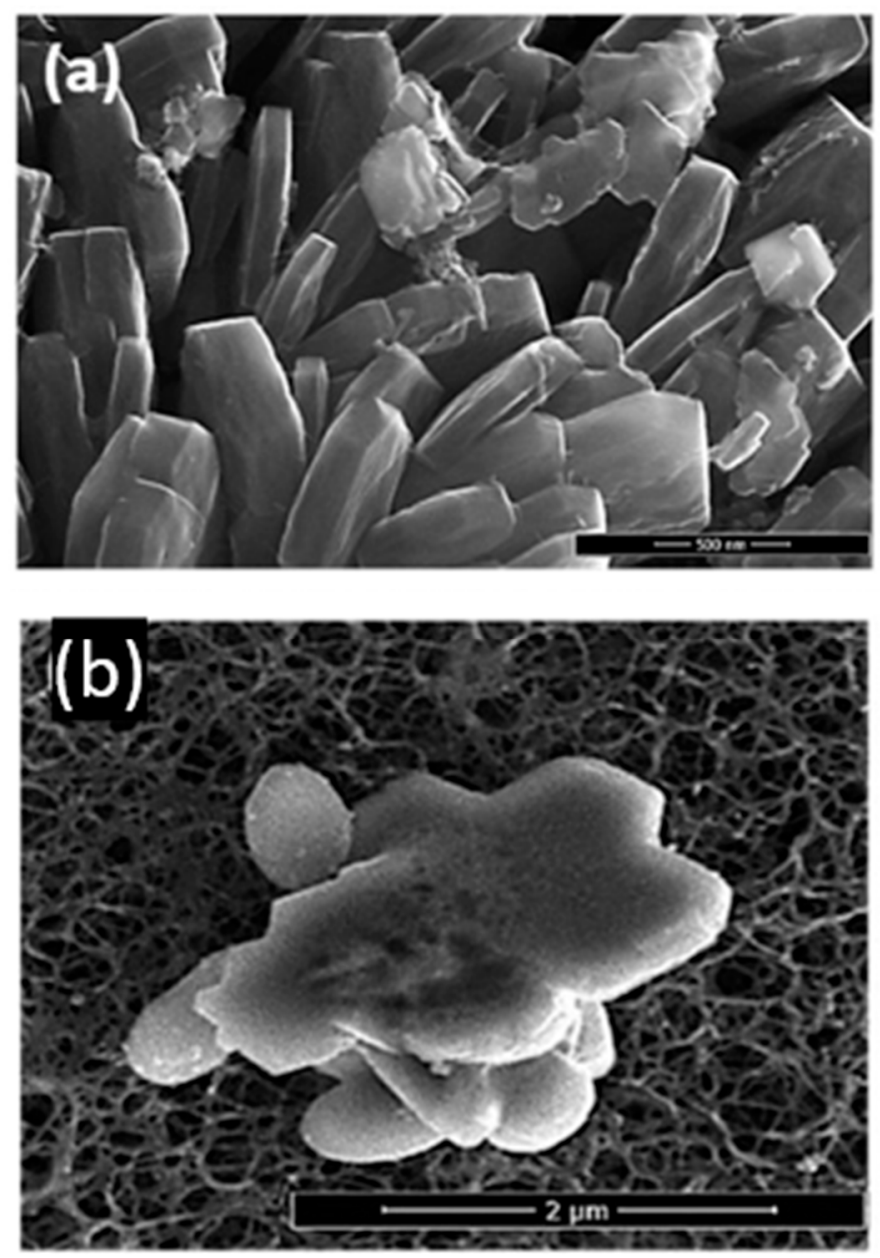

Figure 2. SEM images of (a) aggregated disk-shaped Al NPs obtained from a commercial Al foil; (b) E. coli bacterial cells attached to Al NPs (Adapted from Kunz et al. [29]).

High quality $\mathrm{Al}$ plasmonic films may also be fabricated by thermal evaporation [32]. Coupling of Al NS to Al films has been demonstrated with SPR linewidth narrowing and enhanced scattering efficiency [33]. Nanovoids in Al films have been fabricated and showed localized SPR in extreme UV range [34]. These technological advances in the fabrication of Al NSs showed great promise to optimize biosensing efficiency and, potentially, medical treatment.

\subsection{Treatment Mechanisms}

\subsubsection{Photothermal Therapy (PTT)}

Localized heating and control of photothermal energy in metallic nanoparticles generates several applications including nanoscale sensing [35-37], photothermal imaging [35], photothermal 
therapy [36,38-40], drug delivery [41], nanochemistry [42], and thermoelectric solar cells [43-45]. $\mathrm{Au}$ and Ag NPs have been extensively studied for the applications in photothermal therapy of cancer [46-52] and bacterial inactivation [53-55]. They operate based on the photothermal inactivation mechanism in which the plasmonic NPs absorb light in the visible or near IR spectral range and generate extensive heating which damages the adjacent cancer or bacterial cells.

$\mathrm{Al} \mathrm{NPs} \mathrm{have} \mathrm{the} \mathrm{potential} \mathrm{to} \mathrm{show} \mathrm{similar} \mathrm{effects} \mathrm{with} \mathrm{the} \mathrm{advantages} \mathrm{of} \mathrm{a} \mathrm{broad} \mathrm{spectral} \mathrm{range} \mathrm{and}$ low cost. Al NSs may also provide additional possibilities for synergistic treatment by the combination with other inactivation mechanisms based on UV irradiation, hot electrons, and chemical treatments. Aluminum, as an energetic material [56], has been a source of energetic NSs. Photooxidation of Al NPs by a Xenon flash lamp combined with plasmonic enhancement was used for photothermally activated ignition with high local temperature and local heat control [57]. Thermoplasmonic ignition of Al NPs by the melt dispersion mechanism also showed high local temperatures [58]. Due to large energy density, low ignition temperatures, and fast burning rates [59], Al NPs can also be used for propulsion systems and hydrogen generation. Due to strong plasmonic resonances in a broad spectral range, Al NPs can be utilized for solar light harvesting. Self-assembled Al NPs on 3D porous membranes were used for solar desalination [60].

\subsubsection{Ultraviolet Therapy (UVT)}

Ultraviolet radiation has found applications in photodynamic therapy (PDT), sterilization, and medical diagnostics [61]. UV radiation has been widely used for antibacterial [62] and tissue treatments [63]. UV light has immunomodulatory effects on neutrophils, lymphocytes, monocytes, macrophages, and dendritic cells [63]. UV irradiation of blood has been used for the treatment of septicemia $[64,65]$. Antibiotic-resistant bacteria pose a large threat to the global population [66], and UV radiation therapy needs to be further explored as a potential treatment.

The optical response of plasmonic NPs is governed by scattering and absorption of incident radiation. These two effects provide the main mechanisms of the Al plasmonic UV radiation treatment. The scattering mechanism leads to near-field enhancement with the corresponding increase of the localized surface treatment. On the other hand, absorption of UV radiation may lead to the UV shielding effect and may reduce treatment efficiency [29].

\subsubsection{Hot Electron Therapy (HET)}

Hot carriers generated by coupling of the incident light to surface plasmons have been investigated for applications in plasmon-enhanced photocatalysis [67], photovoltaics [68-70], and photodetection [71-73]. Hot electron (HE) generation depends on the geometry of the plasmonic NPs [74].

HE-based photodetectors [73] may find useful applications, especially in the UV spectral range. The limitations of UV-based photodetectors such as high dark currents and low quantum efficiency $[75,76]$ have previously been addressed using Au and Ag nanostructures. However, due to the poor plasmonic properties of $\mathrm{Au}$ and $\mathrm{Ag}$ in the UV range, other metals such as $\mathrm{Al}, \mathrm{Ga}$, and $\mathrm{Cr}$ have been used [15]. The broad tunable SPR of Al NPs may be useful in fabrication of HE-based photodetectors.

\subsubsection{Toxicity}

Toxicity of metallic NPs has been widely studied and was shown to be inversely dependent on the NP size $[77,78]$. The effects of $\mathrm{Au}, \mathrm{Ag}$, and $\mathrm{Al}$ NPs on human cells and tissues have been investigated [79]. Even though the bulk $\mathrm{Au}$ and $\mathrm{Ag}$ are generally considered to have minimal effects on health, the long-term effects of bulk Ag exposure can cause argyrosis [80]. However, several adverse effects may be caused by $\mathrm{Au}$ and Ag NPs, which need to be taken into consideration when applying the treatment on the human body. For example, Ag has been widely used for antibacterial treatment and disinfection [81] and Ag NPs play a crucial role in healing and treatment within the biomedical field [82]. However, with the diversity in applications such as wound and burn treatment, surgical 
equipment disinfection and drug-delivery, Ag NPs can enter the human body through various ways. The translocation of Ag NPs into various organs in rats was shown [61]. The toxicity of Ag NPs was shown via measurements of cell viability, reactive oxygen species (ROS), or lactate dehydrogenase (LDH) leakage [83]. The viability of mesenchymal stem cells (MSCs) was decreased [84] and lung tissue damage on animal studies was revealed due to the oxidative stress [85] after exposure to Ag NPs, supporting the high toxicity of Ag NPs and presenting a potential risk to human health.

On the other hand, several studies also indicated the absence of toxicity of Ag NPs to certain types of cells. It was shown that 20 and $80 \mathrm{~nm}$ diameter $\mathrm{Au}$ and Ag NPs had lower toxicity to human embryonic neural precursor (HNPC) cells compared to $\mathrm{AgNO}_{3}$, but still affected the growth of HNPCs [79]. Au NPs have lower toxicity compared to Ag NPs. Surface functionalization may affect the toxicity of NPs. For example, Au NPs with cationic trimethylammonium ligands showed cytotoxicity even at a low concentration of Au NPs [86]. On the other hand, many examples of noncationic Au NPs at high concentrations showed the absence of cytotoxicity $[87,88]$. The toxicity of metallic NPs depends on many factors such as NP size, shape, and surface functionalization, which may be optimized to improve the performance of NPs. Size of Au NPs determines the translocation and NP localization within the body [89].

Even though the toxicity of the alumina $\left(\mathrm{Al}_{2} \mathrm{O}_{3}\right)$-based NPs has been studied [90], there has been limited research on the toxicity of Al NPs. Compared with Ag and Au NPs, the Al NPs are expected to have lower cytotoxicity. However, in several cases of high doses, Al NPs have shown some adverse effects. Al NPs reduced the viability of rat alveolar macrophages and limited phagocytic function [91]. It was shown that $\mathrm{Al}$ NPs may have a higher level of cytotoxicity compared to that of $\mathrm{Al}_{2} \mathrm{O}_{3} \mathrm{NPs}$ [91].

In summary, the estimation of the effectiveness of the NP treatment considers toxicity, which, depending on the application, may be optimized by the choice of the chemical composition and morphological parameters. Al NPs, in general, have low toxicity, which could be minimized by increasing the treatment efficiency using the thermal, UV, and hot electron mechanisms described above, reducing the concentration of NPs required to achieve effective treatment.

\section{Applications}

\subsection{Biosensing}

In the field of biosensing, Raman, infrared (IR), and fluorescence spectroscopies have been of outstanding importance in understanding the system response to environments at the molecular level. Raman spectroscopy provides excellent vibrational fingerprints for fast chemical identification. Raman microscopic imaging provides a high spatial resolution with chemical sensitivity, which enables the label-free, on-site in vivo analysis of chemical and structural information of a wide range of biological systems. There has been a significant progress in the development of Raman spectroscopy-based techniques for bacterial cell analysis, clinical diagnosis, structural characterization, and detection of biofilms [92-99]. However, the drawbacks of the spontaneous Raman technique are low sensitivity, particularly for biological samples, and insufficient time resolution due to the long signal accumulation.

Plasmonic NSs have been used in surface-enhanced Raman scattering (SERS) [100-102], and surface-enhanced fluorescence (SEF) [103] to increase the detection sensitivity and speed. These developments stimulated intensive studies of applications in biosensing and optical devices. SERS takes advantage of an electric field enhancement of several orders of magnitude in the vicinity of plasmonic metal NSs. However, the majority of SERS studies used noble metals such as $\mathrm{Au}$ and $\mathrm{Ag}$, and only recently were extended to $\mathrm{Al}$, which has an important advantage of SPR tunability in the UV range [104]. While the Au and Ag NSs are significant in biosensing, Al plasmonics provide similar results with high tunability and low cost. Most biosensing studies were also performed separately from the medical treatment, focusing mainly on sensing and species identification, without the systematic analysis of cell viability. Au and Ag NPs were previously used to enhance the Raman signals of bacteria [97,105-107]. However, most measurements were performed in laboratory conditions on single 
bacterial cells dried on a substrate or in solution mixed with plasmonic NPs [108]. The cytotoxicity of the $\mathrm{Au}$ and $\mathrm{Ag}$ NPs under these conditions has also been poorly understood.

The unique plasmonic properties of Al NPs enable promising applications in biosensing via SERS [109-111] and refractive index measurements [112-115]. In this review, we discuss the combination of medical treatment and sensing using Al NPs towards the development of inexpensive devices that will lead to new breakthroughs not only in biosensing, but also in other fields such as medical treatment, industrial materials processing, and quality control.

Many biomolecules including DNA and proteins have UV resonances, which enable resonance Raman spectroscopy with low fluorescence background [116]. Due to low losses in UV range, Al substrates were used for deep-UV SERS [117], showing several orders of magnitude enhancement for adenine on $\mathrm{Al}$ nanovoid substrates (Figure 3c) [118]. Large enhancement factors of resonance Raman signals of biomolecules using aluminum film-over nanosphere (ALFON) substrates were observed (Figure 3d) [119]. Al bowtie nanoantennas showed large UV resonance Raman enhancement in benzene [120]. Similar performance of SERS on Al NSs was shown in one-to-one comparison with $\mathrm{Ag}$ and $\mathrm{Au}$ [121]. These studies showed successful examples of the combined action of the plasmonic and UV resonance enhancement mechanisms in biosensing.

$\mathrm{SEF}$ has also been used for the detection of biomolecules. For example, Al substrates may provide effective adenine fluorescence enhancement in the UV spectral range [122]. Weak fluorescence of biomolecules such as proteins and DNA [123-125] was enhanced by Al NPs [126-128]. $\mathrm{Al}$ nanostructured substrates were used to enhance the fluorescence of proteins with a different number of tryptophan residues (Figure 3a) [129]. The weak intrinsic fluorescence of adenine was enhanced by Al NP arrays upon UV excitation (Figure 3b) [130]. Polyelectrolyte layer-by-layer assembly with Al NPs was used to enhance the fluorescence intensity of BSA and IgG [127].
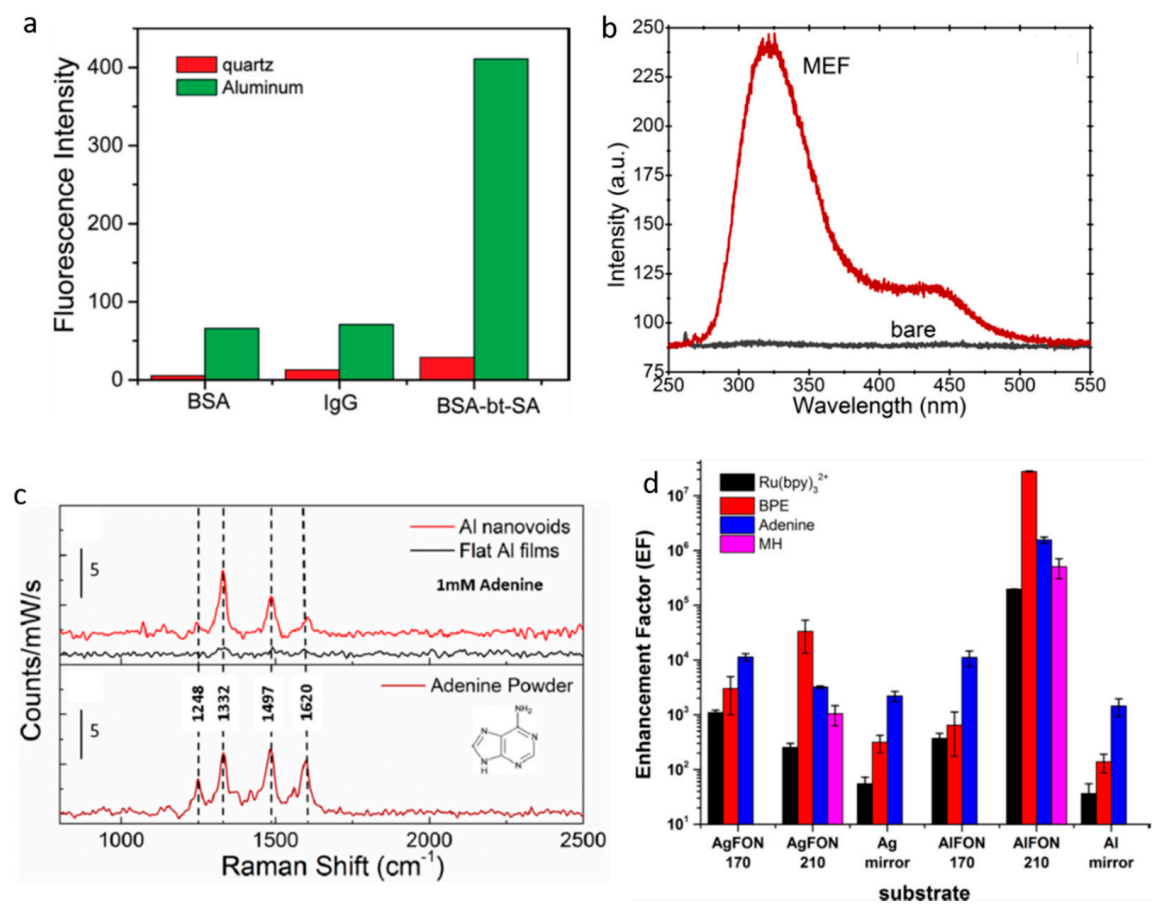

Figure 3. Biosensing using Al NSs. (a) Fluorescence intensities of biomolecules show the enhancement on $\mathrm{Al}$ nanostructured substrates compared to quartz. (Adapted from Ray et al. [129]). (b) Fluorescence spectra of adenine on Al NP array show large enhancement compared to bare quartz. (Adapted from Jha et al. [130]). (c) Surface-enhanced Raman scattering (SERS) of adenine on Al nanovoids. (Adapted from Ding et al. [118]). (d) Enhancement factors of biomolecules on various substrates show largest resonance Raman enhancement on ALFON. (Adapted from Sharma et al. [119]). 


\subsection{Plasmonic Medicine}

\subsubsection{Plasmonic Cancer Diagnosis and Treatment}

Current major cancer treatments involve chemotherapy, radiation, immunotherapy, and surgical resection [131-133]. In addition to the commonly used anticancer drugs [134], new, potent proteasome inhibitors designed to trigger cell death in tumorigenic cells have been used [135]. Radiation therapy has recently advanced, delivering direct, topography-based radiation to patients even through skull or spinal bones [136]. Minimally invasive surgery as well as endoscopic resection has been employed to treat patients with less side-effects than their traditional counterparts $[137,138]$. Despite this progress, there is still a need for alternative therapies [139]. For example, chemotherapy, in addition to being cytotoxic, can induce tumor growth and support its spread throughout the body [140]. New therapies based on photosensitizers and NPs have been developed [141-144]. The benefits of nanotechnology have been applied to healthcare, advancing the nanomedical applications $[145,146]$. $\mathrm{Au}$ NPs have found many applications in cancer treatment due to their high accumulation rates as well as surface chemistry that is amenable to molecular attachments [147-149]. Many different morphologies, including nanospheres, nanorods, nanoshells, nanocages, and triangular nanoprisms, were investigated [12,150-158].

Integration of the in vivo SERS imaging and PTT using Au NPs has been reported [157,158]. SERS imaging with Au and Ag NPs has been used for cancer detection [159], with the potential promise of high sensitivity of biosensing down to femtomolar concentrations [160]. In addition to the enhanced sensitivity, SERS molecular fingerprints permit excellent multiplexing potentials due to the narrow spectral width of Raman peaks [161,162]. Additional advantages of SERS include the ability to use a single excitation source for multiple probes, reduced photobleaching, and minimal background signal from water [163]. SERS also allows for the possibility of monitoring more than one biomarker at a time, as was shown by the improved accuracy of lung cancer diagnostics using functionalized hollow Au nanospheres [164]. SERS imaging enhanced the reproducibility of point-based analysis [165]. The development of Au nano-popcorn SERS probes that integrate selective cell targeting has led to localized heating, and selective cancer cell damage [166]. Aptamers and SERS nanotag reporters can be co-anchored on the surface of Au NPs, leading to precise cancer detection and efficient treatment [167]. SERS nanotags on hollow Au nanospheres showed negligible cytotoxicity and recognized MCF-7 cells with high specificity and selectivity [168].

Al plasmonic substrates for SERS-based cancer diagnosis were fabricated using femtosecond laser ablation [169]. This resulted in wrinkled Al NSs, which showed strong molecular SERS signals from crystal violet and cysteine and were used for in vitro cancer detection.

Photodynamic therapy (PDT) also benefits from Au NPs to increase the photosensitizer efficiency for cancer treatment [170-173] and wound healing [174]. Several challenges for NP-based phototherapy include passive accumulation of NPs [175], limited accessibility of NIR light [176], and biodegradability [177]. Al NPs are promising candidates to address these issues due to their broad spectral response and unique chemical properties.

Hot electron generation mechanism (HET), described above, plays an important role in plasmonic phototherapy. For example, femtosecond transient absorption spectroscopy studies revealed the dynamics of temperature evolution and photo-induced HE generation in Au NPs [178]. The interplay of high temperature and HE effects could provide an improved synergistic cancer treatment. A combination of carbon nanotubes (CNTs) and Ag NPs have shown an advancement in PTT using hot electrons [179]. Hot electrons generated in Au NPs were used in biomedical applications. HET showed a synergistic combination of PTT and PDT on HeLa cells by generation of reactive oxygen species (ROS) from $\mathrm{TiO}_{2}$ Au nanorod (NR) conjugates (Figure 4a,b) [180]. A different mechanism of photothermal therapy of HeLa cells was also shown by using continuous wave and pulsed laser sources on $\mathrm{Au}$ NPs to produce singlet oxygen $\left({ }^{1} \mathrm{O}_{2}\right)$ by hot electrons (Figure 4c) [181]. 
a

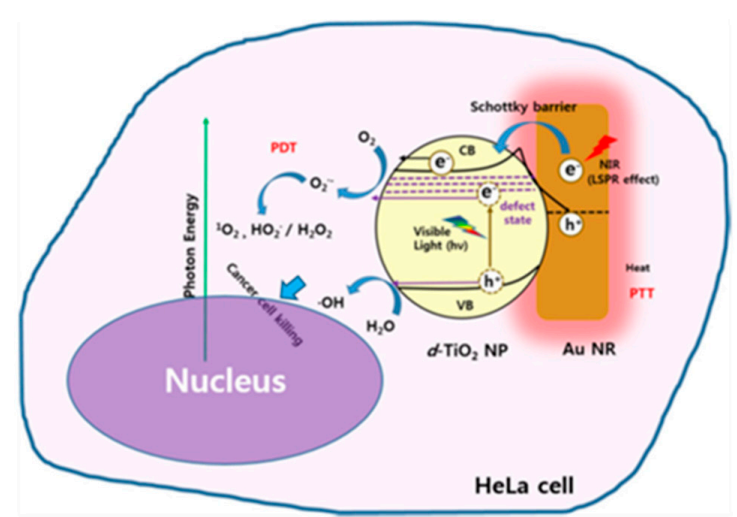

C

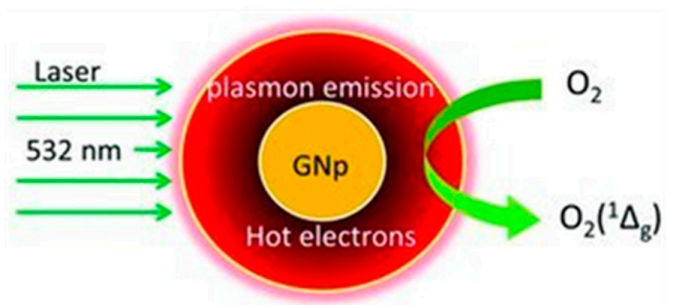

b

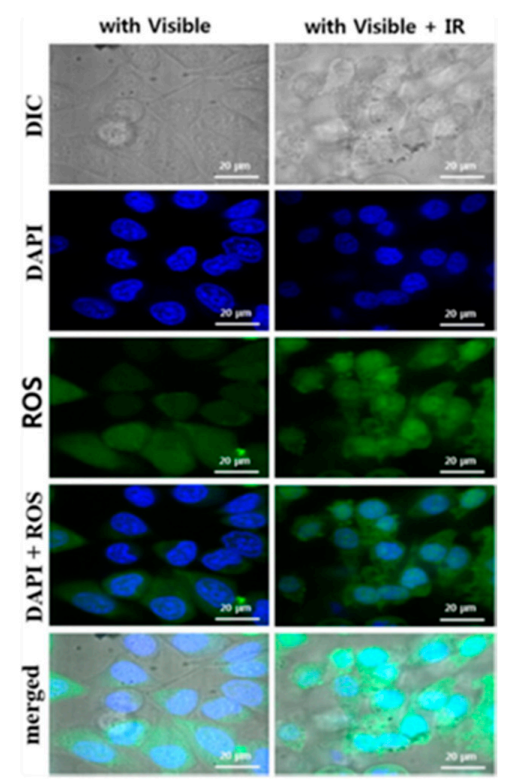

Figure 4. Mechanisms of hot electron generation by Au NPs and their applications. (a) Mechanism for the treatment of HeLa cells under visible and NIR radiation using $\mathrm{TiO}_{2} \mathrm{Au}$ NR conjugates. (b) A combination of visible and IR radiation shows stronger green fluorescence than visible light only, implying enhanced reactive oxygen species (ROS) generation by synergistic effect of visible light and heat generation, leading to high cell death efficacy. (Adapted from Lee et al. [180]). (c) Schematic of singlet oxygen generation upon laser irradiation of naked Au NPs. (Adapted from Pasparakis et al. [181]).

The biomedical applications of hot electrons go beyond PTT and PDT. Hot electron transfer from Au NPs was used to generate plasmon-induced activated (PIA) water with reduced intermolecular hydrogen bonds [182]. PIA water has shown anti-inflammatory and anti-oxidative properties, thereby preventing the oxidative stress caused by the acute inflammation [183].

Alumina $\left(\mathrm{Al}_{2} \mathrm{O}_{3}\right)$ NPs have also been used in cancer therapy. Poly- $\gamma$-glutamic acid functionalized alumina nanoparticles ( $\gamma$-PAN) were evaluated for protein adsorption ability, and found to lower cell viability in a prostate cancer cell (PC-3) line through ROS production and oxidative stress [184]. Therapeutic cancer vaccination based on T-cells is hindered by difficulties to produce large amounts of cells using current vaccine carrier systems [185]. $\mathrm{Al}_{2} \mathrm{O}_{3}$ NPs were shown to carry antigens to autophagosomes in dendritic cells, reducing the number of antigens required to activate T-cells [186]. It was found that immunization of mice with $\mathrm{Al}_{2} \mathrm{O}_{3} \mathrm{NPs}$ conjugated to tumor antigens resulted in tumor regression. These studies encourage the use of $\mathrm{Al}_{2} \mathrm{O}_{3}$ NPs as adjuvants for cancer vaccines [187].

Alumina NPs can depolarize cell membranes, causing cytotoxicity in human epithelial A549 lung cells [188]. In order to enrich ubiquitinated proteins from cancer cells, $\mathrm{Al}_{2} \mathrm{O}_{3} \mathrm{NPs}$ were covalently linked to ubiquitin-binding protein and showed that dendritic cells could more effectively phagocytize the protein/alumina nanoparticle complexes, increasing the antitumor response [189]. Aluminum garnet particles were also used for imaging and PDT of cancer cells [190].

\subsubsection{Plasmonic Antibacterial Treatment}

Over the past years, the number of infections associated with bacteria has increased, many of which are accompanied by the formation of biofilms [97,105-107,191]. Some of the common bacterial pathogens, which cause diseases in humans, are E. coli, S. aureus, V. cholerae, P. aeruginosa, E. faecalis, S. epidermidis, S. viridans, K. pneumonia, and P. mirabilis. Many bacteria developed tolerance/resistance against common organic antibacterial agents and continue to be one of the serious health challenges worldwide. Therefore, developing point-of-care devices for direct and early detection and treatment of 
infections is the need of the hour. In this context, NPs with unique physicochemical characteristics have proven effectiveness for imaging, diagnosis, and therapy. However, real-time detection/diagnosis and quantitative evaluation of the type of pathogens are still a challenging task. Nevertheless, certain properties of some metal NPs, such as Al, Ag, and Au NPs, can be combined with smart optical techniques, such as handheld fluorescence and Raman spectroscopy, to develop affordable and routine diagnosis tools for early pathogen detection and treatment effectiveness assessment.

Microorganisms form complex biofilm structures via self-produced extracellular matrix composed of hydrated extracellular polymeric substances (EPS), which include proteins, lipids, nucleic acids, and polysaccharides [192]. Biofilms are bacterial microenvironments that are widely found in nature, including the human body, and present multiple negative consequences such as energy losses, equipment damage, imbalance in the ecosystem and human diseases $[193,194]$. EPS serves many crucial roles through providing not only mechanical stability for the biofilm but also acting as an external digestive system [195]. Cystic fibrosis (CF) is one of the genetic disorders that affect lungs causing bacterial infection and biofilm formation. The clinical treatment of other types of biofilm infections related to fungi or yeast, such as, for example, oral candidiasis [196], could also benefit from the plasmonic NPs.

Bacterial infections are often associated with biofilms in catheters, valves, and surgery. Microorganisms in biofilms are a common reason for medical device-caused infections, estimating up to $80 \%$ of infections in hospitals related to biofilms [197]. Biofilm-encapsulated bacteria show more than three orders of magnitude larger antibiotic resistance compared to their planktonic counterparts [198]. As a result, biofilm treatment presents a big challenge both for traditional antibiotic [199] and alternative plasmonic NP treatments.

Various plasmonic metal (such as $\mathrm{Au}, \mathrm{Ag}, \mathrm{Cu}, \mathrm{Al}$ ) and metal oxide (such as $\mathrm{TiO}_{2}, \mathrm{ZnO}$, and $\mathrm{MgO}$ ) NPs were investigated for bacterial cell and biofilm inactivation [200]. Au and Ag NPs have been most widely studied separately and in combined antibiotic treatments [201,202]. However, there are limitations that need to be addressed to translate the $\mathrm{Au}$ and $\mathrm{Ag}$ treatments to a broad range of bacterial and environmental conditions. For example, Pseudomonas and E. coli bacteria were shown to develop resistance to Ag NPs after multiple exposures [203]. $\mathrm{TiO}_{2} \mathrm{NPs}$ showed toxicity to healthy cells and tissues via oxidative DNA damage in human cells even without photoactivation [204]. $\mathrm{AgNO}_{3}$ used as an antibacterial treatment of eye infection in infants was shown to have potential toxicity in corneal damage [205].

Al plasmonics may provide an alternative biofilm sensing and treatment approach that could be less expensive, more scalable, less toxic, and more efficient under certain conditions. There has been much less research on $\mathrm{Al}$ plasmonic applications to antibacterial treatment. Here, we review the benefits and drawbacks of using Al NPs and plasmonic substrates for biomedical applications.

Monitoring and treatment of biofilms plays an important role in biomedical and industrial applications. Methods for monitoring biofilm formation, its mechanical stability, and early detection provide many benefits. For example, biofilm monitoring techniques based on a combination of SPR, leaky mode spectroscopy, and attenuated total internal reflection spectroscopy (ATR) on Al films were used to monitor the daily growth of Cytophaga biofilm in various environments (Figure 5) [206]. Chemical stability of $\mathrm{Al}$ compared to $\mathrm{Ag}$ in aqueous environments provides an advantage of $\mathrm{Al}$ plasmonics in biomedical applications, in addition to the low cost. Moreover, the metal toxicity also needs to be considered for a specific application [206]. Biofilm formation monitoring via SPR is based on measuring the refractive index of the suspension of microorganisms and nutrients that interact with the Al plasmonic substrate, which requires proper control measurements and calibrations. 
A

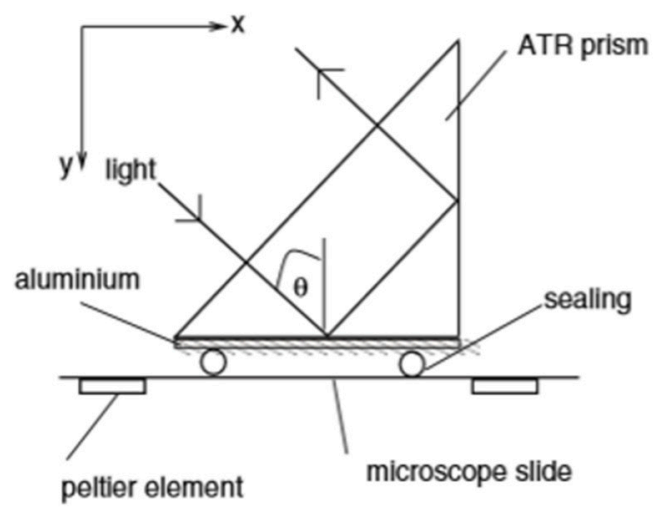

B

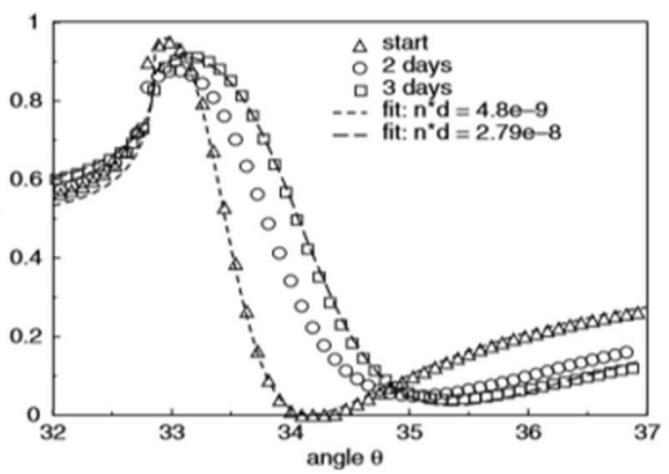

Figure 5. (A) Optical setup for monitoring biofilm formation through Al SPR. (B) SPR shifts of Al film in contact with a biofilm. (Adapted from Leitz et al. [206]).

Monitoring the SPR shift of Al plasmonic substrates in an aqueous organic environment containing Pseudomonas aeruginosa allowed for bacterial biofilm sensing via extracellular polymeric substance (EPS) formation, and to evaluate the $\mathrm{Al}$ corrosion over time [207]. Low corrosion rates of $\mathrm{Al}$ in the presence of the biofilm show the advantage of Al plasmonic sensing compared to that of $\mathrm{Ag}$, which is less stable in the aqueous solution and may more easily detach from the plasmonic sensing device.

Due to the challenges of the Al plasmonic nanostructure fabrication, it is desirable to explore the alternative approaches. Previous work used a commercial plasmonic Al-covered digital versatile disk (DVD) to inactivate E. coli and Geobacillus stearothermophilus via $785 \mathrm{~nm}$ laser-induced heating, showing promising effective hyperthermal sterilization with inexpensive, scalable substrates (Figure 6) [208]. The antibacterial effect was based on the thermal inactivation mechanism using NIR excitation. It can be further enhanced by combining it with the UV excitation with ROS inactivation mechanisms. The control experiment on an $\mathrm{Al}$-covered flat $\mathrm{Si}$ wafer showed a low sterilization efficiency, confirming the SPR-enabled Al plasmonic heating effect (Figure 6C).

Bacterial viability culture tests were performed by scraping the treated bacteria off the DVD and placing the carbenicillin-resistant $E$. coli on LB agar to eliminate contamination. A similar procedure was repeated for thermally-resistant $G$. stearothermophilus spores cultured at $55^{\circ} \mathrm{C}$ without carbenicillin. The effect of the thermally resistant G. stearothermophilus treatment on Al-covered DVD confirms the high temperature effect. This approach may provide an effective, inexpensive, and scalable strategy for improved medical device sterilization and food safety.

It is desirable to combine the plasmonic bacterial treatment with simultaneous monitoring of the treatment efficiency. Recent studies of inactivation and bacterial viability detection on noble metal Au and Ag NPs reported promising results [209]. However, the nature of the enhancement (electromagnetic vs. chemical) remained unclear and the controllability of inactivation was limited. 
A

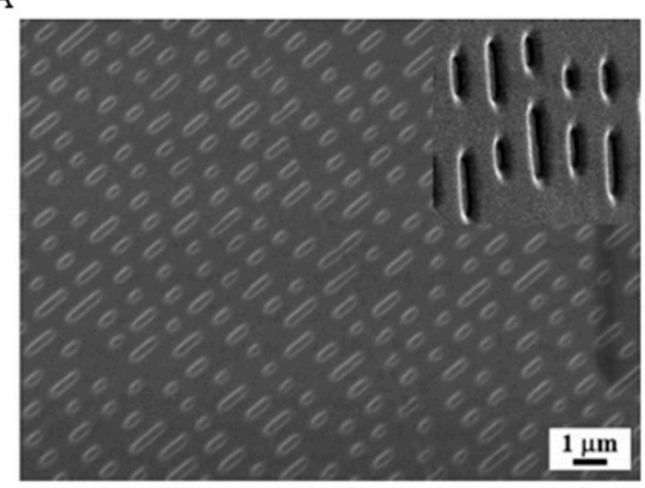

C

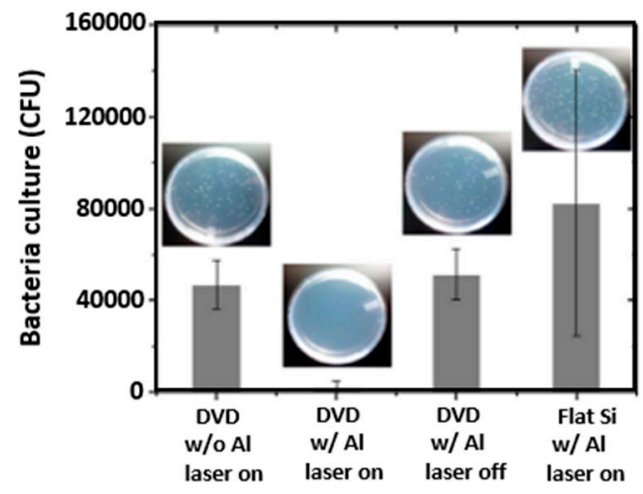

B

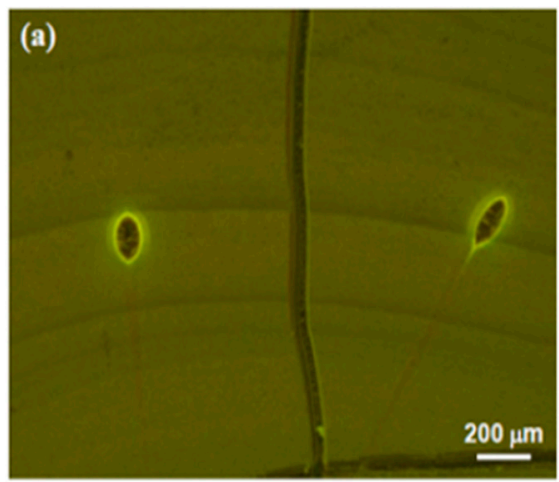

D

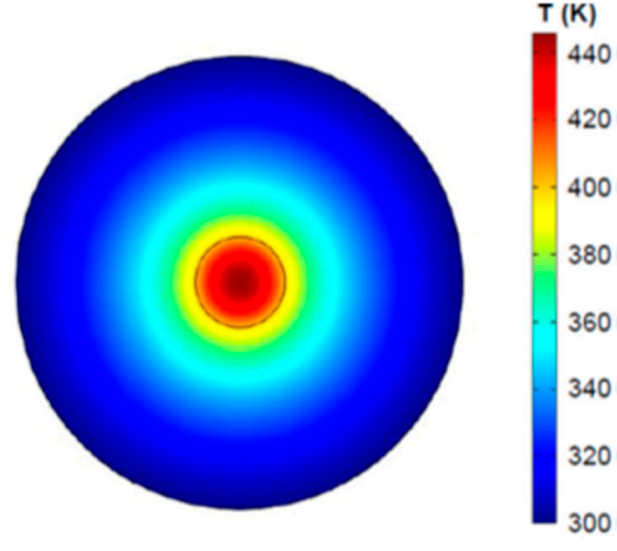

Figure 6. (A) Scanning electron microscopy (SEM) image of Al plasmonic substrate made of an inexpensive commercial DVD of a King Kong, 2005 movie, showing patterned rod-shaped Al nanostructures. Inset shows a magnified part of the substrate. (B) Fluorescence image of two $785 \mathrm{~nm}$ laser-illuminated spots in GFP tagged E. coli-covered DVD, showing laser-induced thermal damage. (C) Photograph of bacterial cultures and counts in colony-forming units (CFU) of E. coli on DVD and flat Al-covered Si showing efficient bacterial inactivation due to Al plasmonic treatment. (D) Simulated distribution of temperature of a $2 \mathrm{~mm}$ diameter DVD piece illuminated by a $400 \mu \mathrm{m}$ diameter laser spot, showing high temperature $\mathrm{T}>400 \mathrm{~K}$, enough to inactivate bacteria. (Adapted from Dou et al. [208]).

\section{Enhancing Al Plasmonic Effects}

\subsection{Alloys and Composites}

Plasmonic metal alloys have been of considerable interest [210-212] for enhanced optical properties, reduced chemical reactivity, and optical loss [213]. Alloying of Al with coinage metals has shown promising applications. For example, Al addition to Au was shown to be an effective bleaching agent for jewelry, but also showed the undesirable increase in optical loss [214]. On the other hand, the addition of $\mathrm{Al}$ to $\mathrm{Cu}$ showed the enhanced SPR [215].

The addition of Al to Ag has also been of widespread interest [216-221]. It has been reported that the thermal stability of Ag was improved by alloying it with Al [74,222-224]. Optical properties of $\alpha$-phase $\mathrm{Ag}-\mathrm{Al}$ thin films revealed that the addition of $1-2 \%$ of $\mathrm{Al}$ not only reduced the surface roughness of Ag but was also beneficial for its dielectric function applications [219]. Incorporation of a low percentage of $\mathrm{Al}$ assisted in the continuous film growth of $\mathrm{Ag}$, which is highly desirable for large area flexible organic photovoltaics (OPVs). The addition of $\mathrm{Al}$ in $\mathrm{Ag}$ is a promising alternative to transport conductivity electrodes because of its high transmittance and high conductivity [223]. Tunable plasmonic properties of Al-Ag alloy NPs with radius $\sim 10 \mathrm{~nm}$ embedded in silica showed a linear increase in the width of SPR bands in both $\mathrm{Ag}_{1-x} \mathrm{Al}_{\mathrm{x}}$ and $\mathrm{Al}_{1-x} \mathrm{Ag}_{\mathrm{x}}$ alloys (Figure 7a,b) [224]. 
The combination of the strong SEF of Ag and large UV SPR in Al NPs was investigated by FDTD simulations of the Ag-Al bimetallic alloy to increase the emission enhancement of amino acids NATA-tyr and NATA (Figure 7c,d) and proteins in the UV range [225].

a

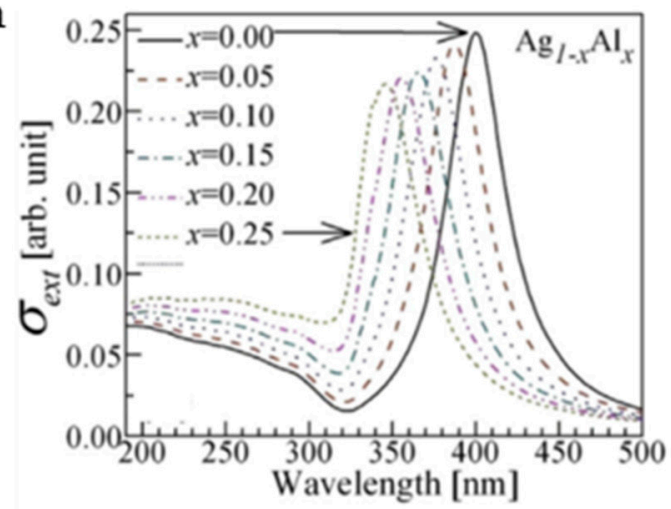

$\mathrm{C}$

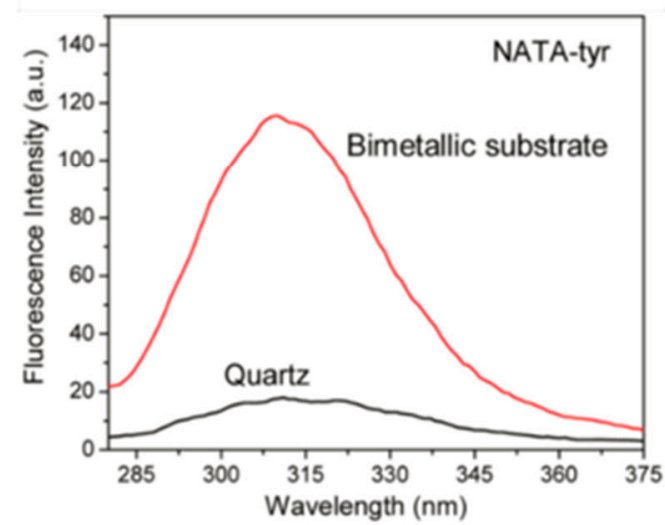

$\mathrm{b}$

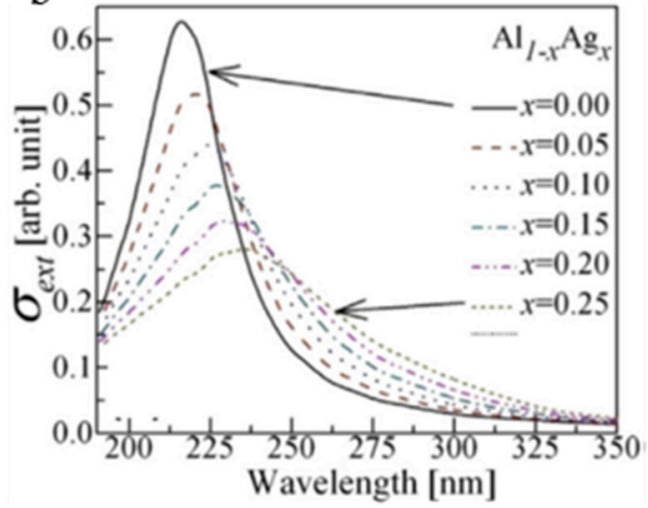

d

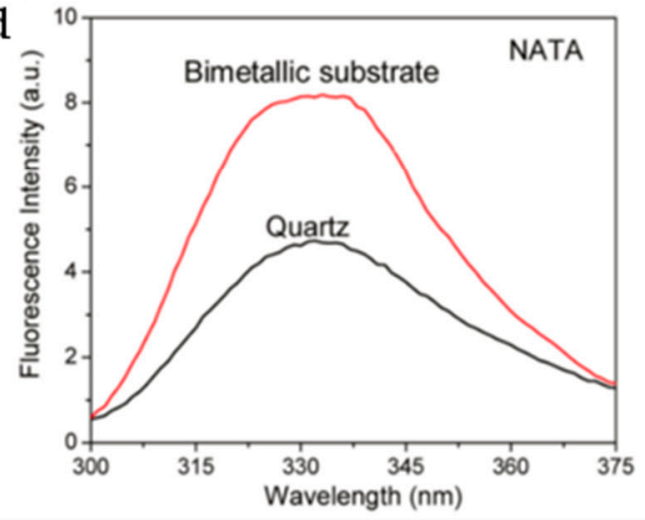

Figure 7. Extinction spectra of $\mathrm{Ag}_{1-\mathrm{x}} \mathrm{Al}_{\mathrm{x}}$ and $\mathrm{Al}_{1-\mathrm{x}} \mathrm{Ag}_{\mathrm{x}}$ alloys for varying molar concentrations of $\mathrm{Al}$ : (a) With increasing concentration of Al, the SPR peak blueshifts from the elemental Ag NP. (b) SPR peak redshifts from the elemental Al NP with increasing concentration of Ag. (Adapted from Kuiri [224]). $(\mathbf{c}, \mathbf{d})$ Fluorescence enhancement of NATA-tyr and NATA on quartz and bimetallic substrates. (Adapted from Chowdhury et al. [225]).

\subsection{Chemical Enhancement}

The chemical mechanism (CM) of surface enhancement is commonly used to explain additional contributions to the enhancement factor beyond the electromagnetic near-field enhancement (EM). It is attributed to the chemical interactions between the adsorbed biomolecules and the plasmonic substrate leading to the changes in electronic structure and charge transfer processes [226-230]. The CM enhancement depends on the nature of the molecule and NP and can play a bigger role in the $\mathrm{Al}$ plasmonic systems due to the smaller EM contribution compared to that of Au and Ag. This opens the possibilities to explore the interplay of both $\mathrm{CM}$ and EM effects in $\mathrm{Al}$ plasmonic substrates.

For example, the optical response of pyridine adsorbed on Ag and Al NPs was studied using time-dependent density functional theory (TDDFT), revealing significant differences between molecule-substrate interactions [231]. Figure 8 shows the simulated optical absorption spectra of a pyridine molecule adsorbed perpendicular $(A, B)$ and parallel $(C, D)$ to the NP surface of $\mathrm{Ag}(\mathrm{A}, \mathrm{C})$ and $\mathrm{Al}(\mathrm{B}, \mathrm{D}) \mathrm{NPs}$. These results showed that the spectra are not significantly influenced by the pyridine orientation in the case of Ag NPs, but showed drastic changes for the Al NPs. The corresponding transition density plots showed larger contributions of the plasmonic excitation in Ag NPs via the dipolar shape of the transition densities (Figure 8A,C). They also showed larger contributions of the charge transfer excitation in Al NPs via the mixed densities on NPs and large densities on pyridine 
(Figure 8B,D). The parallel orientation showed a larger charge transfer contribution compared to the perpendicular orientation. These results indicate potential promising applications of the $\mathrm{Al}$ plasmonics to investigate single-molecule interactions relevant to biosensing, light harvesting, and photocatalysis.
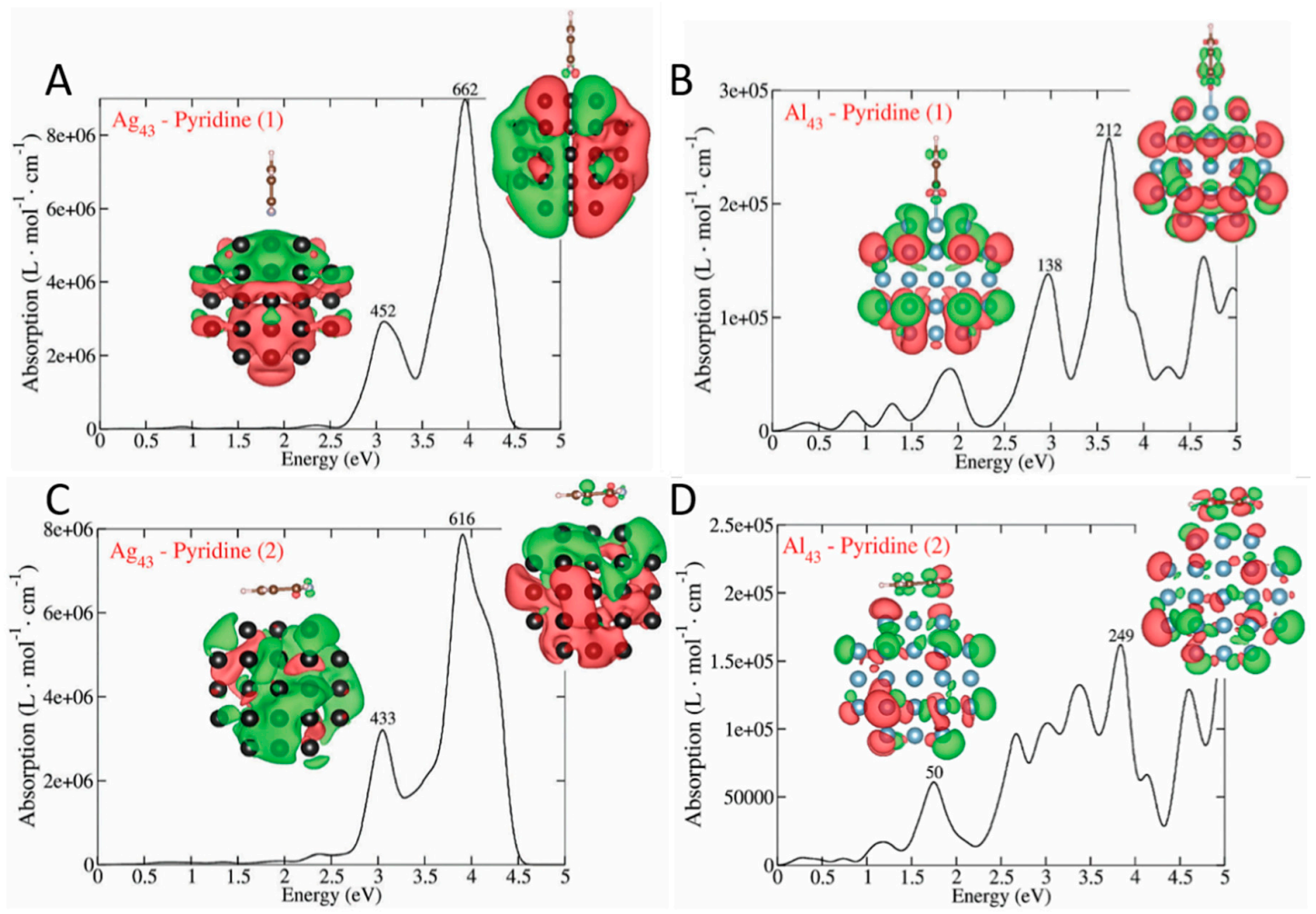

Figure 8. Time-dependent density functional theory (TDDFT) simulations of the optical response of pyridine adsorbed on Ag and Al NSs: Optical absorption spectra and transition density plots of the NP-pyridine systems with perpendicular $(\mathbf{A}, \mathbf{B})$ and parallel $(\mathbf{C}, \mathbf{D})$ orientations of pyridine, with respect to the NP surface. Red and green colors denote electron density accumulation (depletion) regions during the excitation, respectively. (Adapted from Mokkath [231]).

\subsection{Quantum Enhancement}

One drawback of $\mathrm{Al}$ plasmonics is the strong plasmon damping relative to $\mathrm{Au}$ and $\mathrm{Ag}$. As a result, near-field enhancement in Al NSs is weaker than that in Au and Ag NSs [216]. An approach to minimize losses by coupling plasmonic NSs with gain media based on surface plasmon amplification by stimulated emission of radiation (spaser) was proposed [232,233] and experimentally realized in noble metal NPs $[234,235]$. This stimulated generation of coherent plasmons leads to stronger near fields at the surface of NSs, which could be used for enhanced phototherapy. For example, a wound or tumor may be treated with Al NSs and irradiated with a weak UV light, serving as incoherent pump, g, to excite the three-level gain media, such as molecular dyes or quantum dots (Figure 9a). The zoomed-in picture of one of the Al NSs is shown in Figure 9b. It represents a spherical nanoshell filled with gain media particles with energy levels matching the NS SPRs. The localized UV near fields of Al NPs may be used for the enhanced treatment near the surface of the wound without affecting the surrounding healthy tissue. The role of Al NSs in this process is the nanoscale focusing of UV light at the surface of NS attached to the target tissue, lowering the required incident power, and increasing the treatment efficiency. Experimental realizations of Al nanolasers have been reported [236-238]. However, their practical applications require optimization of structural and optical properties [239]. 

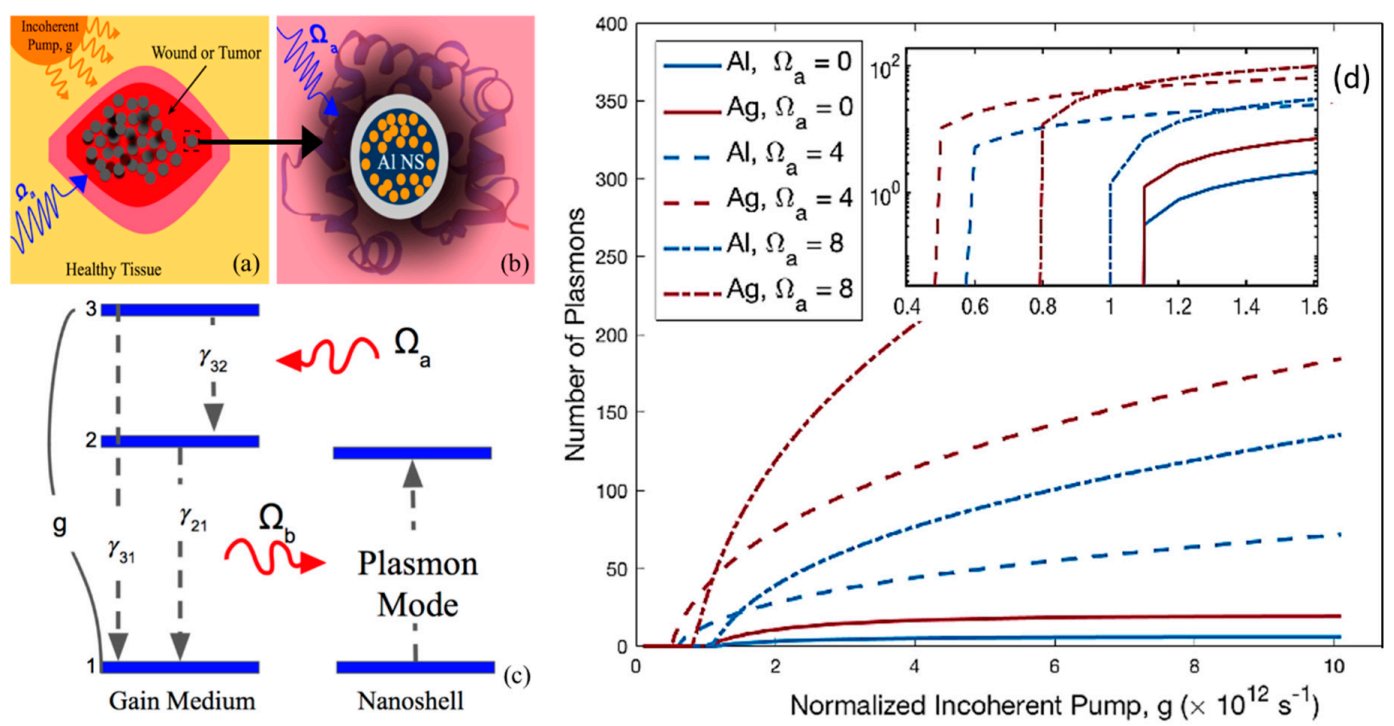

Figure 9. Quantum medicine model of wound or cancer treatment using Al NSs irradiated by incoherent UV light and coherent visible or infrared laser. Al NSs in the wound localize the incident UV fields at the surface, leading to faster and more efficient treatment with lower UV dose. (a) Schematic picture of Al NSs inside a wound or tumor. (b) Zoomed-in schematic of Al nanoshell filled with gain media particles surrounded by biomolecules. (c) Energy level diagram showing various states of the Al NS (nanoshell) and gain medium, coupled by UV pump $(\mathrm{g})$ and an additional laser drive $\left(\Omega_{\mathrm{a}}\right)$ field. The quantum coherence generated between states 2 and 3 by the drive field leads to stronger near fields (d) and more efficient treatment. (Adapted from Withers et al. [216]).

The overall efficiency is limited by the near-field enhancement factors of the Al NSs and the maximum allowed UV dose for the target tissue. These limits may be overcome by using the quantum optical effects, proposed for the Ag [240] and recently extended to the Al NSs [216]. The efficiency of plasmon generation in Al NS spasers can be increased by generating quantum coherence between the states of the gain media using an additional drive laser field that can break the detailed balance and suppress the radiative damping (Figure $9 \mathrm{c}$ ). Figure $9 \mathrm{~d}$ shows a comparison of the number of plasmons generated in $\mathrm{Al}$ and $\mathrm{Ag}$ NS spasers as a function of the pump, g, for different drive fields, $\Omega_{\mathrm{a}}$. It shows more than an order of magnitude increase of the number of plasmons in Al NSs due to the quantum coherence generated by the drive. The inset of Figure $9 \mathrm{~d}$ shows the corresponding decrease of the spasing threshold, that is, the required minimum pump strength to generate spaser action. That is another advantage of the quantum coherence as it reduces the UV dose absorbed by tissue due to the UV pump excitation. Other methods may be used to further enhance the performance of Al NS spasers to optimize energy transfer and field enhancement by the coherent control of field propagation in coupled plasmonic systems [241], as well as by transient [242] and feedback-controlled effects [243], leading to more efficient quantum medicine.

\section{Translational Applications and Outlook}

The quantum medicine approach may also be used to improve the UV treatment of coronaviruses. Effective pathogen inactivation systems based on UV radiation have been developed for West Nile, Zika, hepatitis E, dengue, and other viruses [244-251]. However, the dosage of the effective UV radiation varies with different viruses and genome types, depending on the size and other factors [252-259]. The underlying mechanisms of virus inactivation is the degradation of the genome or capsid proteins [260-264].

UV irradiation can have synergistic effects in combination with other treatments. Acid and heat stable enteroviruses EV70 and EV71 were treated with UV radiation [265-268]. A dual wavelength (260 and $280 \mathrm{~nm}$ ) UVC-LED device was used for the inactivation of human enteroviruses [266]. 
Heat, UV radiation, and chemical treatments of viruses have been analyzed [269]. Among the most UV-resistant viruses, adenovirus (AD41) was inactivated using germicidal UV radiation (254 nm) with dosages ranging from 75 to $225 \mathrm{~mJ} / \mathrm{cm}^{2}$ [270]. Viral capsid damage in adenovirus (AD5) by low- (LP) and medium-pressure (MP) UV radiation revealed a more efficient inactivation in the $230-245 \mathrm{~nm}$ range [271]. Additional experiments on AD5 and AD41 showed the enhanced effects of UV inactivation followed by chlorine treatment [272]. Comparison of the UVC irradiation of the non-enveloped feline calicivirus (FCV) at 255, 261, 277, and $281 \mathrm{~nm}$ revealed a larger absorbance at $255 \mathrm{~nm}$, making it more suitable for the treatment [273].

The Covid-19 (SARS-CoV-2) pandemic has been a cause of major concerns and challenges to understand the viral epidemiology and clinical characteristics [274,275]. A functioning methodology of the virus inactivation has been the urgent research question. The use of UV radiation as a method of SARS-associated virus inactivation has been proposed by clinicians and scientists [276]. For example, the use of germicidal UV (UVGI) radiation for the decontamination of N95 filtering facepiece respirators (N95FFs) has been reported [277-280]. Detailed UVGI decontamination of the N95FFs procedure was also developed, which involves the inactivation of bacterial and viral surrogate organisms [281]. Novel approaches for practical build-at-home UVC disinfection systems for decontaminating PPE have also been actively developed [282].

Previous studies used UV radiation to inactivate coronaviruses, facing successes and challenges. For example, germicidal UVC had low efficiency for the inactivation of canine coronavirus (CCoV), requiring up to 3 days of exposure to achieve viral inactivation [283]. On the other hand, the successful coronavirus inactivation by UV radiation, heat treatment, $\mathrm{pH}$ changes, formalin, and glutaraldehyde treatments has been reported $[284,285]$. UVC inactivation of SARS-CoV revealed that a 1 min exposure of $254 \mathrm{~nm}$ UVC leads to partial inactivation, with a complete inactivation achieved upon $15 \mathrm{~min}$ exposure [285]. These challenges need to be addressed to develop effective real-time disinfection devices, and quantum-coherence-enhanced Al NSs provide a promising approach.

\section{Summary}

In summary, several biomedical applications of technologies that could be improved by using aluminum plasmonics were highlighted. The toxicity of various NPs was discussed and, while other metals are more prevalent in NP research, aluminum is less toxic and therefore requires less material to achieve effective treatment.

Aluminum plasmonics in SERS and SEF have the important advantage of SPR tunability in the $\mathrm{UV}$ range. While $\mathrm{Au}$ and $\mathrm{Ag}$ NPs are of great importance in biosensing, $\mathrm{Al}$ NPs provide similar results with higher tunability and lower cost. In plasmonic medicine, Au and Ag NPs have been investigated in PTT and SERS imaging. While NP-based PDT has limitations, Al NPs are promising candidates to overcome the issues due to their broad spectral response and unique chemical properties. Several enhancements to aluminum plasmonic effects such as alloys, chemical enhancement, and quantum effects were discussed.

In conclusion, this review underlines the opportunities of the aluminum plasmonics research in biomedical applications including biosensing, imaging, and phototherapy. Al NSs are promising candidates for these improvements with the advantages of low toxicity and cost. It is our hope that future research will focus more heavily on aluminum plasmonics and on the great potential for developing the field of quantum medicine.

Funding: This research received no external funding.

Conflicts of Interest: The authors declare no conflict of interest. 


\section{References}

1. Knight, M.W.; King, N.S.; Liu, L.; Everitt, H.O.; Nordlander, P.; Halas, N.J. Aluminum for plasmonics. ACS Nano 2014, 8, 834-840. [CrossRef] [PubMed]

2. Tan, S.J.; Zhang, L.; Zhu, D.; Goh, X.M.; Wang, Y.M.; Kumar, K.; Qiu, C.-W.; Yang, J.K. Plasmonic color palettes for photorealistic printing with aluminum nanostructures. Nano Lett. 2014, 14, 4023-4029. [CrossRef] [PubMed]

3. Zhu, X.; Hossain, G.M.I.; George, M.; Farhang, A.; Cicek, A.; Yanik, A.A. Beyond Noble Metals: High Q-Factor Aluminum Nanoplasmonics. ACS Photonics 2020. [CrossRef]

4. Wang, B.; Singh, S.C.; Lu, H.; Guo, C. Design of Aluminum Bowtie Nanoantenna Array with Geometrical Control to Tune LSPR from UV to Near-IR for Optical Sensing. Plasmonics 2019, 1-13. [CrossRef]

5. Lu, D.Y.; Cao, X.; Wang, K.J.; He, M.D.; Wang, D.; Li, J.; Zhang, X.M.; Liu, L.; Luo, J.H.; Li, Z. Broadband reflective lens in visible band based on aluminum plasmonic metasurface. Opt. Express 2018, 26, 34956-34964. [CrossRef]

6. Norek, M.; Włodarski, M.; Matysik, P. UV plasmonic-based sensing properties of aluminum nanoconcave arrays. Curr. Appl. Phys. 2014, 14, 1514-1520. [CrossRef]

7. Martin, J.; Proust, J.; Gérard, D.; Plain, J. Localized surface plasmon resonances in the ultraviolet from large scale nanostructured aluminum films. Opt. Mater. Express 2013, 3, 954-959. [CrossRef]

8. Zhang, F.; Martin, J.; Plain, J. Long-term stability of plasmonic resonances sustained by evaporated aluminum nanostructures. Opt. Mater. Express 2019, 9, 85-94. [CrossRef]

9. Argyropoulos, C.; Monticone, F.; D’Aguanno, G.; Alù, A. Plasmonic nanoparticles and metasurfaces to realize Fano spectra at ultraviolet wavelengths. Appl. Phys. Lett. 2013, 103, 143113. [CrossRef]

10. Ershov, A.E.; Gerasimov, V.S.; Bikbaev, R.G.; Polyutov, S.P.; Karpov, S.V. Mode coupling in arrays of Al nanoparticles. J. Quant. Spectrosc. Radiat. Transf. 2020, 106961. [CrossRef]

11. Zhang, F.; Proust, J.; Gérard, D.; Plain, J.; Martin, J. Reduction of plasmon damping in aluminum nanoparticles with rapid thermal annealing. J. Phys. Chem. C 2017, 121, 7429-7434. [CrossRef]

12. Zoric, I.; Zach, M.; Kasemo, B.; Langhammer, C. Gold, platinum, and aluminum nanodisk plasmons: Material independence, subradiance, and damping mechanisms. ACS Nano 2011, 5, 2535-2546. [CrossRef]

13. Langhammer, C.; Schwind, M.; Kasemo, B.; Zoric, I. Localized surface plasmon resonances in aluminum nanodisks. Nano Lett. 2008, 8, 1461-1471. [CrossRef] [PubMed]

14. Tseng, M.L.; Yang, J.; Semmlinger, M.; Zhang, C.; Nordlander, P.; Halas, N.J. Two-dimensional active tuning of an aluminum plasmonic array for full-spectrum response. Nano Lett. 2017, 17, 6034-6039. [CrossRef] [PubMed]

15. Knight, M.W.; Liu, L.; Wang, Y.; Brown, L.; Mukherjee, S.; King, N.S.; Everitt, H.O.; Nordlander, P.; Halas, N.J. Aluminum plasmonic nanoantennas. Nano Lett. 2012, 12, 6000-6004. [CrossRef] [PubMed]

16. Mohammadi, A.; Sandoghdar, V.; Agio, M. Gold, copper, silver and aluminum nanoantennas to enhance spontaneous emission. J. Comput. Theor. Nanosci. 2009, 6, 2024-2030. [CrossRef]

17. Castro-Lopez, M.; Brinks, D.; Sapienza, R.; van Hulst, N.F. Aluminum for nonlinear plasmonics: Resonance-driven polarized luminescence of Al, Ag, and Au nanoantennas. Nano Lett. 2011, 11, 4674-4678. [CrossRef]

18. Du, C.; Cai, W.; Wu, W.; Li, L.; Xiang, Y.; Ren, M.; Zhang, X.; Xu, J. Evolution and Coupling of Plasmonic Modes in Single-Crystal Aluminum Nanoridge Antennas. ACS Photonics 2018, 5, 2983-2989. [CrossRef]

19. Swartz, M.; Rodriguez, M.; Quast, A.D.; Cooper, C.T.; Blair, S.; Shumaker-Parry, J.S. Aluminum nanocrescent plasmonic antennas fabricated by copper mask nanosphere template lithography. J. Phys. Chem. C 2016, 120, 20597-20603. [CrossRef]

20. Forestiere, C.; Handin, A.; Dal Negro, L. Enhancement of molecular fluorescence in the UV spectral range using aluminum nanoantennas. Plasmonics 2014, 9, 715-725. [CrossRef]

21. Ghorbani, H.R. A review of methods for synthesis of Al nanoparticles. Orient. J. Chem. 2014, 30, 1941-1949. [CrossRef]

22. Haber, J.A.; Buhro, W.E. Kinetic instability of nanocrystalline aluminum prepared by chemical synthesis; facile room-temperature grain growth. J. Am. Chem. Soc. 1998, 120, 10847-10855. [CrossRef]

23. Chandra, S.; Kumar, A.; Tomar, P.K. Synthesis of Al nanoparticles: Transmission electron microscopy, thermal and spectral studies. Spectrochim. Acta Part A Mol. Biomol. Spectrosc. 2012, 92, 392-397. [CrossRef] [PubMed] 
24. Li, H.; Meziani, M.J.; Lu, F.; Bunker, C.E.; Guliants, E.A.; Sun, Y.-P. Templated synthesis of aluminum nanoparticles-A new route to stable energetic materials. J. Phys. Chem. C 2009, 113, 20539-20542. [CrossRef]

25. McClain, M.J.; Schlather, A.E.; Ringe, E.; King, N.S.; Liu, L.; Manjavacas, A.; Knight, M.W.; Kumar, I.; Whitmire, K.H.; Everitt, H.O. Aluminum nanocrystals. Nano Lett. 2015, 15, 2751-2755. [CrossRef]

26. Clark, B.D.; Jacobson, C.R.; Lou, M.; Yang, J.; Zhou, L.; Gottheim, S.; DeSantis, C.J.; Nordlander, P.; Halas, N.J. Aluminum nanorods. Nano Lett. 2018, 18, 1234-1240. [CrossRef] [PubMed]

27. Clark, B.D.; Jacobson, C.R.; Lou, M.; Renard, D.; Wu, G.; Bursi, L.; Ali, A.S.; Swearer, D.F.; Tsai, A.-L.; Nordlander, P. Aluminum nanocubes have sharp corners. ACS Nano 2019, 13, 9682-9691. [CrossRef] [PubMed]

28. Swearer, D.F.; Leary, R.K.; Newell, R.; Yazdi, S.; Robatjazi, H.; Zhang, Y.; Renard, D.; Nordlander, P.; Midgley, P.A.; Halas, N.J. Transition-metal decorated aluminum nanocrystals. ACS Nano 2017, 11, 10281-10288. [CrossRef]

29. Kunz, J.N.; Voronine, D.V.; Lu, W.; Liege, Z.; Lee, H.W.H.; Zhang, Z.; Scully, M.O. Aluminum plasmonic nanoshielding in ultraviolet inactivation of bacteria. Sci. Rep. 2017, 7, 1-10. [CrossRef] [PubMed]

30. Manikandan, M.; Gopal, J.; Chun, S. Sonophysical cost effective rapid indigenous preparation of aluminium particles via exfoliation of aluminium foil. RSC Adv. 2016, 6, 32405-32413. [CrossRef]

31. Lee, M.H.; Lim, N.; Ruebusch, D.J.; Jamshidi, A.; Kapadia, R.; Lee, R.; Seok, T.J.; Takei, K.; Cho, K.Y.; Fan, Z. Roll-to-roll anodization and etching of aluminum foils for high-throughput surface nanotexturing. Nano Lett. 2011, 11, 3425-3430. [CrossRef]

32. McPeak, K.M.; Jayanti, S.V.; Kress, S.J.; Meyer, S.; Iotti, S.; Rossinelli, A.; Norris, D.J. Plasmonic films can easily be better: Rules and recipes. ACS Photonics 2015, 2, 326-333. [CrossRef] [PubMed]

33. Sobhani, A.; Manjavacas, A.; Cao, Y.; McClain, M.J.; García de Abajo, F.J.; Nordlander, P.; Halas, N.J. Pronounced linewidth narrowing of an aluminum nanoparticle plasmon resonance by interaction with an aluminum metallic film. Nano Lett. 2015, 15, 6946-6951. [CrossRef] [PubMed]

34. Zhu, Y.; Nakashima, P.N.; Funston, A.M.; Bourgeois, L.; Etheridge, J. Topologically enclosed aluminum voids as plasmonic nanostructures. ACS Nano 2017, 11, 11383-11392. [CrossRef] [PubMed]

35. Boyer, D.; Tamarat, P.; Maali, A.; Lounis, B.; Orrit, M. Photothermal imaging of nanometer-sized metal particles among scatterers. Science 2002, 297, 1160-1163. [CrossRef]

36. Gobin, A.M.; Lee, M.H.; Halas, N.J.; James, W.D.; Drezek, R.A.; West, J.L. Near-infrared resonant nanoshells for combined optical imaging and photothermal cancer therapy. Nano Lett. 2007, 7, 1929-1934. [CrossRef]

37. Chan, G.H.; Zhao, J.; Schatz, G.C.; Van Duyne, R.P. Localized surface plasmon resonance spectroscopy of triangular aluminum nanoparticles. J. Phys. Chem. C 2008, 112, 13958-13963. [CrossRef]

38. Jain, P.K.; El-Sayed, I.H.; El-Sayed, M.A. Au nanoparticles target cancer. Nano Today 2007, 2, 18-29. [CrossRef]

39. Lukianova-Hleb, E.Y.; Ren, X.; Zasadzinski, J.A.; Wu, X.; Lapotko, D.O. Plasmonic Nanobubbles Enhance Efficacy and Selectivity of Chemotherapy Against Drug-Resistant Cancer Cells. Adv. Mater. 2012, 24, 3831-3837. [CrossRef]

40. Lukianova-Hleb, E.Y.; Belyanin, A.; Kashinath, S.; Wu, X.; Lapotko, D.O. Plasmonic nanobubble-enhanced endosomal escape processes for selective and guided intracellular delivery of chemotherapy to drug-resistant cancer cells. Biomaterials 2012, 33, 1821-1826. [CrossRef]

41. Ghosh, P.; Han, G.; De, M.; Kim, C.K.; Rotello, V.M. Gold nanoparticles in delivery applications. Adv. Drug Deliv. Rev. 2008, 60, 1307-1315. [CrossRef] [PubMed]

42. Qiu, J.; Wei, W.D. Surface plasmon-mediated photothermal chemistry. J. Phys. Chem. C 2014, 118, $20735-20749$. [CrossRef]

43. Tursunov, M.N.; Muminov, R.A.; Tukfatullin, O.F.; Yuldoshev, I.A.; Abdullaev, E.T. Photothermal electric battery based on silicon solar cells. Appl. Sol. Energy 2011, 47, 63-65. [CrossRef]

44. Linic, S.; Christopher, P.; Ingram, D.B. Plasmonic-metal nanostructures for efficient conversion of solar to chemical energy. Nat. Mater. 2011, 10, 911-921. [CrossRef]

45. Hägglund, C.; Apell, S.P. Plasmonic near-field absorbers for ultrathin solar cells. J. Phys. Chem. Lett. 2012, 3 , 1275-1285. [CrossRef]

46. Huang, X.; El-Sayed, I.H.; Qian, W.; El-Sayed, M.A. Cancer cell imaging and photothermal therapy in the near-infrared region by using gold nanorods. J. Am. Chem. Soc. 2006, 128, 2115-2120. [CrossRef]

47. Huang, X.; Jain, P.K.; El-Sayed, I.H.; El-Sayed, M.A. Plasmonic photothermal therapy (PPTT) using gold nanoparticles. Lasers Med. Sci. 2008, 23, 217. [CrossRef] 
48. Lal, S.; Clare, S.E.; Halas, N.J. Nanoshell-enabled photothermal cancer therapy: Impending clinical impact. Acc. Chem. Res. 2008, 41, 1842-1851. [CrossRef]

49. Bardhan, R.; Lal, S.; Joshi, A.; Halas, N.J. Theranostic nanoshells: From probe design to imaging and treatment of cancer. Acc. Chem. Res. 2011, 44, 936-946. [CrossRef]

50. Jain, S.; Hirst, D.G.; O'sullivan, J.M. Gold nanoparticles as novel agents for cancer therapy. Br. J. Radiol. 2012, 85, 101-113. [CrossRef]

51. Choi, W.I.; Sahu, A.; Kim, Y.H.; Tae, G. Photothermal cancer therapy and imaging based on gold nanorods. Ann. Biomed. Eng. 2012, 40, 534-546. [CrossRef] [PubMed]

52. Lee, J.; Chatterjee, D.K.; Lee, M.H.; Krishnan, S. Gold nanoparticles in breast cancer treatment: Promise and potential pitfalls. Cancer Lett. 2014, 347, 46-53. [CrossRef] [PubMed]

53. Zharov, V.P.; Mercer, K.E.; Galitovskaya, E.N.; Smeltzer, M.S. Photothermal nanotherapeutics and nanodiagnostics for selective killing of bacteria targeted with gold nanoparticles. Biophys. J. 2006, 90, 619-627. [CrossRef] [PubMed]

54. Huang, W.-C.; Tsai, P.-J.; Chen, Y.-C. Functional gold nanoparticles as photothermal agents for selective-killing of pathogenic bacteria. Nanomedicine 2007, 2, 777-787. [CrossRef] [PubMed]

55. Gharatape, A.; Davaran, S.; Salehi, R.; Hamishehkar, H. Engineered gold nanoparticles for photothermal cancer therapy and bacteria killing. RSC Adv. 2016, 6, 111482-111516. [CrossRef]

56. Dreizin, E.L. Metal-based reactive nanomaterials. Prog Energy Combust. Sci. 2009, 35, 141-167. [CrossRef]

57. Abboud, J.E.; Chong, X.; Zhang, M.; Zhang, Z.; Jiang, N.; Roy, S.; Gord, J.R. Photothermally activated motion and ignition using aluminum nanoparticles. Appl. Phys. Lett. 2013, 102, 023905. [CrossRef]

58. Mutlu, M.; Kang, J.-H.; Raza, S.; Schoen, D.; Zheng, X.; Kik, P.G.; Brongersma, M.L. Thermoplasmonic ignition of metal nanoparticles. Nano Lett. 2018, 18, 1699-1706. [CrossRef]

59. Shende, R.; Subramanian, S.; Hasan, S.; Apperson, S.; Thiruvengadathan, R.; Gangopadhyay, K.; Gangopadhyay, S.; Redner, P.; Kapoor, D.; Nicolich, S. Nanoenergetic composites of CuO nanorods, nanowires, and Al-nanoparticles. Propellants Explos. Pyrotech. Int. J. Deal. Sci. Technol. Asp. Energ. Mater. 2008, 33, 122-130. [CrossRef]

60. Zhou, L.; Tan, Y.; Wang, J.; Xu, W.; Yuan, Y.; Cai, W.; Zhu, S.; Zhu, J. 3D self-assembly of aluminium nanoparticles for plasmon-enhanced solar desalination. Nat. Photonics 2016, 10, 393. [CrossRef]

61. Lloyd, J.J. Ultraviolet radiation in medicine. Encycl. Med Devices Instrum. 2006, 6, 473-490.

62. Diffey, B.L. Solar ultraviolet radiation effects on biological systems. Phys. Med. Biol. 1991, 36, 299. [CrossRef] [PubMed]

63. Gupta, A.; Avci, P.; Dai, T.; Huang, Y.-Y.; Hamblin, M.R. Ultraviolet radiation in wound care: Sterilization and stimulation. Adv. Wound Care 2013, 2, 422-437. [CrossRef] [PubMed]

64. Miley, G.; Christensen, J.A. Ultraviolet blood irradiation therapy: Further studies in acute infections. Am. J. Surg. 1947, 73, 486-493. [CrossRef]

65. Hamblin, M.R. Ultraviolet irradiation of blood: "The cure that time forgot"? In Ultraviolet Light in Human Health, Diseases and Environment; Springer: Berlin/Heidelberg, Germany, 2017; pp. 295-309.

66. Yoneyama, H.; Katsumata, R. Antibiotic resistance in bacteria and its future for novel antibiotic development. Biosci. Biotechnol. Biochem. 2006, 70, 1060-1075. [CrossRef] [PubMed]

67. Zhou, L.; Zhang, C.; McClain, M.J.; Manjavacas, A.; Krauter, C.M.; Tian, S.; Berg, F.; Everitt, H.O.; Carter, E.A.; Nordlander, P. Aluminum nanocrystals as a plasmonic photocatalyst for hydrogen dissociation. Nano Lett. 2016, 16, 1478-1484. [CrossRef]

68. De Arquer, F.P.G.; Mihi, A.; Konstantatos, G. Molecular interfaces for plasmonic hot electron photovoltaics. Nanoscale 2015, 7, 2281-2288. [CrossRef]

69. Wang, F.; Melosh, N.A. Plasmonic energy collection through hot carrier extraction. Nano Lett. 2011, 11, 5426-5430. [CrossRef]

70. Leenheer, A.J.; Narang, P.; Lewis, N.S.; Atwater, H.A. Solar energy conversion via hot electron internal photoemission in metallic nanostructures: Efficiency estimates. J. Appl. Phys. 2014, 115, 134301. [CrossRef]

71. Brongersma, M.L.; Halas, N.J.; Nordlander, P. Plasmon-induced hot carrier science and technology. Nat. Nanotechnol. 2015, 10, 25. [CrossRef]

72. Knight, M.W.; Sobhani, H.; Nordlander, P.; Halas, N.J. Photodetection with active optical antennas. Science 2011, 332, 702-704. [CrossRef] [PubMed] 
73. Gong, T.; Munday, J.N. Angle-independent hot carrier generation and collection using transparent conducting oxides. Nano Lett. 2015, 15, 147-152. [CrossRef] [PubMed]

74. Ahmadivand, A.; Sinha, R.; Vabbina, P.K.; Karabiyik, M.; Kaya, S.; Pala, N. Hot electron generation by aluminum oligomers in plasmonic ultraviolet photodetectors. Opt. Express 2016, 24, 13665-13678. [CrossRef] [PubMed]

75. Hu, G.C.; Shan, C.X.; Zhang, N.; Jiang, M.M.; Wang, S.P.; Shen, D.Z. High gain $\mathrm{Ga}_{2} \mathrm{O}_{3}$ solar-blind photodetectors realized via a carrier multiplication process. Opt. Express 2015, 23, 13554-13561. [CrossRef]

76. Li, D.; Sun, X.; Song, H.; Li, Z.; Chen, Y.; Jiang, H.; Miao, G. Realization of a high-performance GaN UV detector by nanoplasmonic enhancement. Adv. Mater. 2012, 24, 845-849. [CrossRef]

77. Yang, L.; Watts, D.J. Particle surface characteristics may play an important role in phytotoxicity of alumina nanoparticles. Toxicol. Lett. 2005, 158, 122-132. [CrossRef]

78. Mostafalou, S.; Mohammadi, H.; Ramazani, A.; Abdollahi, M. Different Biokinetics of Nanomedicines Linking to Their Toxicity; An Overview; Springer: Berlin/Heidelberg, Germany, 2013.

79. Söderstjerna, E.; Johansson, F.; Klefbohm, B.; Johansson, U.E. Gold-and silver nanoparticles affect the growth characteristics of human embryonic neural precursor cells. PLoS ONE 2013, 8, e58211. [CrossRef]

80. Drake, P.L.; Hazelwood, K.J. Exposure-related health effects of silver and silver compounds: A review. Ann. Occup. Hyg. 2005, 49, 575-585.

81. Clement, J.L.; Jarrett, P.S. Antibacterial silver. Met. Based Drugs 1994, 1, 467-482. [CrossRef]

82. Burdușel, A.-C.; Gherasim, O.; Grumezescu, A.M.; Mogoantă, L.; Ficai, A.; Andronescu, E. Biomedical applications of silver nanoparticles: An up-to-date overview. Nanomaterials 2018, 8, 681. [CrossRef]

83. Hussain, S.M.; Hess, K.L.; Gearhart, J.M.; Geiss, K.T.; Schlager, J.J. In vitro toxicity of nanoparticles in BRL 3A rat liver cells. Toxicol. In Vitro 2005, 19, 975-983. [CrossRef] [PubMed]

84. Ricles, L.M.; Nam, S.Y.; Sokolov, K.; Emelianov, S.Y.; Suggs, L.J. Function of mesenchymal stem cells following loading of gold nanotracers. Int. J. Nanomed. 2011, 6, 407. [CrossRef]

85. Kaewamatawong, T.; Banlunara, W.; Maneewattanapinyo, P.; Thammachareon, C.; Ekgasit, S. Acute and subacute pulmonary toxicity caused by a single intratracheal instillation of colloidal silver nanoparticles in mice: Pathobiological changes and metallothionein responses. J. Environ. Pathol. Toxicol. Oncol. 2014, 33. [CrossRef] [PubMed]

86. Boisselier, E.; Astruc, D. Gold nanoparticles in nanomedicine: Preparations, imaging, diagnostics, therapies and toxicity. Chem. Soc. Rev. 2009, 38, 1759-1782. [CrossRef] [PubMed]

87. Connor, E.E.; Mwamuka, J.; Gole, A.; Murphy, C.J.; Wyatt, M.D. Gold nanoparticles are taken up by human cells but do not cause acute cytotoxicity. Small 2005, 1, 325-327. [CrossRef] [PubMed]

88. Wang, S.; Lu, W.; Tovmachenko, O.; Rai, U.S.; Yu, H.; Ray, P.C. Challenge in understanding size and shape dependent toxicity of gold nanomaterials in human skin keratinocytes. Chem. Phys. Lett. 2008, 463, 145-149. [CrossRef]

89. Gratton, S.E.; Pohlhaus, P.D.; Lee, J.; Guo, J.; Cho, M.J.; DeSimone, J.M. Nanofabricated particles for engineered drug therapies: A preliminary biodistribution study of PRINT ${ }^{\mathrm{TM}}$ nanoparticles. J. Control. Release 2007, 121, 10-18. [CrossRef]

90. Yoon, D.; Woo, D.; Kim, J.H.; Kim, M.K.; Kim, T.; Hwang, E.-S.; Baik, S. Agglomeration, sedimentation, and cellular toxicity of alumina nanoparticles in cell culture medium. J. Nanoparticle Res. 2011, 13, 2543-2551. [CrossRef]

91. Wagner, A.J.; Bleckmann, C.A.; Murdock, R.C.; Schrand, A.M.; Schlager, J.J.; Hussain, S.M. Cellular interaction of different forms of aluminum nanoparticles in rat alveolar macrophages. J. Phys. Chem. B 2007, 111, 7353-7359. [CrossRef]

92. Liu, R.; Liu, J.; Zhou, X.; Jiang, G. Applications of Raman-based techniques to on-site and in-vivo analysis. TrAC Trends Anal. Chem. 2011, 30, 1462-1476. [CrossRef]

93. Sahoo, P.; Murthy, P.S.; Dhara, S.; Venugopalan, V.P.; Das, A.; Tyagi, A.K. Probing the cellular damage in bacteria induced by GaN nanoparticles using confocal laser Raman spectroscopy. J. Nanopart. Res. 2013, 15, 1841. [CrossRef]

94. Janissen, R.; Murillo, D.M.; Niza, B.; Sahoo, P.K.; Nobrega, M.M.; Cesar, C.L.; Temperini, M.L.; Carvalho, H.F.; De Souza, A.A.; Cotta, M.A. Spatiotemporal distribution of different extracellular polymeric substances and filamentation mediate Xylella fastidiosa adhesion and biofilm formation. Sci. Rep. 2015, 5, 9856. [CrossRef] [PubMed] 
95. Jarvis, R.M.; Goodacre, R. Discrimination of bacteria using surface-enhanced Raman spectroscopy. Anal. Chem. 2004, 76, 40-47. [CrossRef]

96. Sengupta, A.; Mujacic, M.; Davis, E.J. Detection of bacteria by surface-enhanced Raman spectroscopy. Anal. Bioanal. Chem. 2006, 386, 1379-1386. [CrossRef]

97. Premasiri, W.R.; Lee, J.C.; Sauer-Budge, A.; Théberge, R.; Costello, C.E.; Ziegler, L.D. The biochemical origins of the surface-enhanced Raman spectra of bacteria: A metabolomics profiling by SERS. Anal. Bioanal. Chem. 2016, 408, 4631-4647. [CrossRef]

98. Pahlow, S.; Meisel, S.; Cialla-May, D.; Weber, K.; Rösch, P.; Popp, J. Isolation and identification of bacteria by means of Raman spectroscopy. Adv. Drug Deliv. Rev. 2015, 89, 105-120. [CrossRef]

99. Ho, C.-S.; Jean, N.; Hogan, C.A.; Blackmon, L.; Jeffrey, S.S.; Holodniy, M.; Banaei, N.; Saleh, A.A.; Ermon, S.; Dionne, J. Rapid identification of pathogenic bacteria using Raman spectroscopy and deep learning. Nat. Commun. 2019, 10, 1-8. [CrossRef]

100. Moskovits, M.; Stockman, M.I. Surface-Enhanced Raman Scattering Physics and Applications; Springer Science \& Business Media: New York, NY, USA, 2006.

101. Le Ru, E.; Etchegoin, P. Principles of Surface-Enhanced Raman Spectroscopy: And Related Plasmonic Effects; Elsevier: Amsterdam, The Netherlands, 2008.

102. Kiefer, W. Surface Enhanced Raman Spectroscopy: Analytical, Biophysical and Life Science Applications; John Wiley \& Sons: Hoboken, NJ, USA, 2011.

103. Geddes, C.D. Metal-Enhanced Fluorescence; John Wiley \& Sons. Inc.: Hoboken, NJ, USA, 2010.

104. Gérard, D.; Gray, S.K. Aluminium plasmonics. J. Phys. D Appl. Phys. 2014, 48, 184001. [CrossRef]

105. Premasiri, W.R.; Moir, D.T.; Klempner, M.S.; Krieger, N.; Jones, G.; Ziegler, L.D. Characterization of the surface enhanced Raman scattering (SERS) of bacteria. J. Phys. Chem. B 2005, 109, 312-320. [CrossRef]

106. Sengupta, A.; Laucks, M.L.; Davis, E.J. Surface-enhanced Raman spectroscopy of bacteria and pollen. Appl. Spectrosc. 2005, 59, 1016-1023. [CrossRef]

107. Efrima, S.; Zeiri, L. Understanding SERS of bacteria. J. Raman Spectrosc. 2009, 40, 277-288. [CrossRef]

108. Zhou, H.; Yang, D.; Ivleva, N.P.; Mircescu, N.E.; Niessner, R.; Haisch, C. SERS detection of bacteria in water by in situ coating with Ag nanoparticles. Anal. Chem. 2014, 86, 1525-1533. [CrossRef]

109. Gómez, M.; Kadkhodazadeh, S.; Lazzari, M. Surface enhanced Raman scattering (SERS) in the visible range on scalable aluminum-coated platforms. Chem. Commun. 2018, 54, 10638-10641. [CrossRef]

110. Tian, S.; Neumann, O.; McClain, M.J.; Yang, X.; Zhou, L.; Zhang, C.; Nordlander, P.; Halas, N.J. Aluminum nanocrystals: A sustainable substrate for quantitative SERS-based DNA detection. Nano Lett. 2017, 17, 5071-5077. [CrossRef]

111. Kumamoto, Y.; Taguchi, A.; Kawata, S.; Smith, N.I. Deep ultraviolet resonant Raman imaging of a cell. J. Biomed. Opt. 2012, 17, 076001. [CrossRef]

112. Ebbesen, T.W.; Lezec, H.J.; Ghaemi, H.F.; Thio, T.; Wolff, P.A. Extraordinary optical transmission through sub-wavelength hole arrays. Nature 1998, 391, 667-669. [CrossRef]

113. De Leebeeck, A.; Kumar, L.S.; De Lange, V.; Sinton, D.; Gordon, R.; Brolo, A.G. On-chip surface-based detection with nanohole arrays. Anal. Chem. 2007, 79, 4094-4100. [CrossRef]

114. Eftekhari, F.; Escobedo, C.; Ferreira, J.; Duan, X.; Girotto, E.M.; Brolo, A.G.; Gordon, R.; Sinton, D. Nanoholes as nanochannels: Flow-through plasmonic sensing. Anal. Chem. 2009, 81, 4308-4311. [CrossRef]

115. Canalejas-Tejero, V.; Herranz, S.; Bellingham, A.; Moreno-Bondi, M.C.; Barrios, C.A. Passivated aluminum nanohole arrays for label-free biosensing applications. ACS Appl. Mater. Interfaces 2014, 6, 1005-1010. [CrossRef]

116. Li, W.; Ren, K.; Zhou, J. Aluminum-based localized surface plasmon resonance for biosensing. TrAC Trends Anal. Chem. 2016, 80, 486-494. [CrossRef]

117. Jha, S.K.; Ahmed, Z.; Agio, M.; Ekinci, Y.; Löffler, J.F. Deep-UV surface-enhanced resonance Raman scattering of adenine on aluminum nanoparticle arrays. J. Am. Chem. Soc. 2012, 134, 1966-1969. [CrossRef]

118. Ding, T.; Sigle, D.O.; Herrmann, L.O.; Wolverson, D.; Baumberg, J.J. Nanoimprint lithography of Al nanovoids for deep-UV SERS. ACS Appl. Mater. Interfaces 2014, 6, 17358-17363. [CrossRef]

119. Sharma, B.; Cardinal, M.F.; Ross, M.B.; Zrimsek, A.B.; Bykov, S.V.; Punihaole, D.; Asher, S.A.; Schatz, G.C.; Van Duyne, R.P. Aluminum film-over-nanosphere substrates for deep-uv surface-enhanced resonance Raman spectroscopy. Nano Lett. 2016, 16, 7968-7973. [CrossRef] [PubMed] 
120. Li, L.; Fang Lim, S.; Puretzky, A.A.; Riehn, R.; Hallen, H.D. Near-field enhanced ultraviolet resonance Raman spectroscopy using aluminum bow-tie nano-antenna. Appl. Phys. Lett. 2012, 101, 113116. [CrossRef]

121. Rodriguez, R.D.; Sheremet, E.; Nesterov, M.; Moras, S.; Rahaman, M.; Weiss, T.; Hietschold, M.; Zahn, D.R. Aluminum and copper nanostructures for surface-enhanced Raman spectroscopy: A one-to-one comparison to silver and gold. Sens. Actuators B Chem. 2018, 262, 922-927. [CrossRef]

122. Knighton, W.B.; Giskaas, G.O.; Callis, P.R. Fluorescence from adenine cations. J. Phys. Chem. 1982, 86, 49-55. [CrossRef]

123. Eastman, J.W.; Rosa, E.J. The fluorescence of adenine. The effects of solvent and temperature on the quantum yield. Photochem. Photobiol. 1968, 7, 189-201. [CrossRef]

124. Callis, P.R. Electronic states and luminescence of nucleic acid systems. Annu. Rev. Phys. Chem. 1983, 34, 329-357. [CrossRef]

125. Onidas, D.; Markovitsi, D.; Marguet, S.; Sharonov, A.; Gustavsson, T. Fluorescence properties of DNA nucleosides and nucleotides: A refined steady-state and femtosecond investigation. J. Phys. Chem. B 2002, 106, 11367-11374. [CrossRef]

126. Ray, K.; Chowdhury, M.H.; Lakowicz, J.R. Aluminum nanostructured films as substrates for enhanced fluorescence in the ultraviolet-blue spectral region. Anal. Chem. 2007, 79, 6480-6487. [CrossRef]

127. Akbay, N.; Lakowicz, J.R.; Ray, K. Distance-dependent metal-enhanced intrinsic fluorescence of proteins using polyelectrolyte layer-by-layer assembly and aluminum nanoparticles. J. Phys. Chem. C 2012, 116, 10766-10773. [CrossRef]

128. Chowdhury, M.H.; Ray, K.; Gray, S.K.; Pond, J.; Lakowicz, J.R. Aluminum nanoparticles as substrates for metal-enhanced fluorescence in the ultraviolet for the label-free detection of biomolecules. Anal. Chem. 2009, 81, 1397-1403. [CrossRef]

129. Ray, K.; Szmacinski, H.; Lakowicz, J.R. Enhanced fluorescence of proteins and label-free bioassays using aluminum nanostructures. Anal. Chem. 2009, 81, 6049-6054. [CrossRef]

130. Jha, S.K.; Mojarad, N.; Agio, M.; Löffler, J.F.; Ekinci, Y. Enhancement of the intrinsic fluorescence of adenine using aluminum nanoparticle arrays. Opt. Express 2015, 23, 24719-24729. [CrossRef] [PubMed]

131. Bedge, P.A.; Bohara, R.A.; Patil, P.M.; Joshi, M.G.; Bohara, D.A. Current cancer therapies: Focus on hyperthermia and immunotherapy. In Hybrid Nanostructures for Cancer Theranostics; Elsevier: Amsterdam, The Netherlands, 2019; pp. 43-61.

132. Minn, A.J.; Wherry, E.J. Combination cancer therapies with immune checkpoint blockade: Convergence on interferon signaling. Cell 2016, 165, 272-275. [CrossRef] [PubMed]

133. Vlashi, E.; Pajonk, F. Cancer stem cells, cancer cell plasticity and radiation therapy. Semin Cancer Biol. 2015, 31, 28-35. [CrossRef] [PubMed]

134. Bertsimas, D.; Zhuo, Y.D. Novel Target Discovery of Existing Therapies: Path to Personalized Cancer Therapy. Inf. J. Optim. 2020, 2, 1-13. [CrossRef]

135. Yerlikaya, A.; Okur, E. An investigation of the mechanisms underlying the proteasome inhibitor bortezomib resistance in PC3 prostate cancer cell line. Cytotechnology 2020, 72, 121-130. [CrossRef]

136. Tanaka, Y.; Oita, M.; Inomata, S.; Fuse, T.; Akino, Y.; Shimomura, K. Impact of patient positioning uncertainty in noncoplanar intracranial stereotactic radiotherapy. J. Appl. Clin. Med. Phys. 2020, 21, 89-97. [CrossRef]

137. Auffenberg, G.B.; Curry, M.; Gennarelli, R.; Blum, K.A.; Elkin, E.; Russo, P. Comparison of Cancer-specific Outcomes following Minimally-Invasive and Open Surgical Resection of Early-Stage Kidney Cancer from a National Cancer Registry. J. Urol. 2020, 203, 1094-1100. [CrossRef]

138. Lowe, D.; Saleem, S.; Arif, M.O.; Sinha, S.; Brooks, G. Role of Endoscopic Resection Versus Surgical Resection in Management of Malignant Colon Polyps: A National Cancer Database Analysis. J. Gastrointest. Surg. 2020, 24, 177-187. [CrossRef] [PubMed]

139. Guan, X. Cancer metastases: Challenges and opportunities. Acta Pharm. Sin. B 2015, 5, 402-418. [CrossRef] [PubMed]

140. Daenen, L.G.; Roodhart, J.M.; van Amersfoort, M.; Dehnad, M.; Roessingh, W.; Ulfman, L.H.; Derksen, P.W.; Voest, E.E. Chemotherapy enhances metastasis formation via VEGFR-1-expressing endothelial cells. Cancer Res. 2011, 71, 6976-6985. [CrossRef] [PubMed]

141. Huang, X.; El-Sayed, M.A. Gold nanoparticles: Optical properties and implementations in cancer diagnosis and photothermal therapy. J. Adv. Res. 2010, 1, 13-28. [CrossRef] 
142. Huang, H.-C.; Ramos, J.; Grandhi, T.S.P.; Potta, T.; Rege, K. Gold nanoparticles in cancer imaging and therapeutics. Nano Life 2010, 1, 289-307. [CrossRef]

143. Obaid, G.; Broekgaarden, M.; Bulin, A.-L.; Huang, H.-C.; Kuriakose, J.; Liu, J.; Hasan, T. Photonanomedicine: A convergence of photodynamic therapy and nanotechnology. Nanoscale 2016, 8, 12471-12503. [CrossRef]

144. Shi, J.; Kantoff, P.W.; Wooster, R.; Farokhzad, O.C. Cancer nanomedicine: Progress, challenges and opportunities. Nat. Rev. Cancer 2017, 17, 20. [CrossRef]

145. Qin, Z.; Bischof, J.C. Thermophysical and biological responses of gold nanoparticle laser heating. Chem. Soc. Rev. 2012, 41, 1191-1217. [CrossRef]

146. Macdonald, I.J.; Dougherty, T.J. Basic principles of photodynamic therapy. J. Porphyr. Phthalocyanines 2001, 5, 105-129. [CrossRef]

147. Dreaden, E.C.; Alkilany, A.M.; Huang, X.; Murphy, C.J.; El-Sayed, M.A. The golden age: Gold nanoparticles for biomedicine. Chem. Soc. Rev. 2012, 41, 2740-2779. [CrossRef]

148. Lim, E.-K.; Kim, T.; Paik, S.; Haam, S.; Huh, Y.-M.; Lee, K. Nanomaterials for theranostics: Recent advances and future challenges. Chem. Rev. 2015, 115, 327-394. [CrossRef] [PubMed]

149. Turkevich, J.; Stevenson, P.C.; Hillier, J. The formation of colloidal gold. J. Phys. Chem. 1953, 57, 670-673. [CrossRef]

150. Martin, C.R. Nanomaterials: A membrane-based synthetic approach. Science 1994, 266, 1961-1966. [CrossRef]

151. Liz-Marzán, L.M.; Giersig, M.; Mulvaney, P. Synthesis of nanosized gold-silica core-shell particles. Langmuir 1996, 12, 4329-4335. [CrossRef]

152. Skrabalak, S.E.; Au, L.; Li, X.; Xia, Y. Facile synthesis of Ag nanocubes and Au nanocages. Nat. Protoc. 2007, 2, 2182. [CrossRef]

153. Shankar, S.S.; Rai, A.; Ankamwar, B.; Singh, A.; Ahmad, A.; Sastry, M. Biological synthesis of triangular gold nanoprisms. Nat. Mater. 2004, 3, 482-488. [CrossRef]

154. Shanmugam, V.; Selvakumar, S.; Yeh, C.-S. Near-infrared light-responsive nanomaterials in cancer therapeutics. Chem. Soc. Rev. 2014, 43, 6254-6287. [CrossRef]

155. Alkilany, A.M.; Thompson, L.B.; Boulos, S.P.; Sisco, P.N.; Murphy, C.J. Gold nanorods: Their potential for photothermal therapeutics and drug delivery, tempered by the complexity of their biological interactions. Adv. Drug Deliv. Rev. 2012, 64, 190-199. [CrossRef] [PubMed]

156. Rastinehad, A.R.; Anastos, H.; Wajswol, E.; Winoker, J.S.; Sfakianos, J.P.; Doppalapudi, S.K.; Carrick, M.R.; Knauer, C.J.; Taouli, B.; Lewis, S.C. Gold nanoshell-localized photothermal ablation of prostate tumors in a clinical pilot device study. Proc. Natl. Acad. Sci. USA 2019, 116, 18590-18596. [CrossRef]

157. von Maltzahn, G.; Centrone, A.; Park, J.-H.; Ramanathan, R.; Sailor, M.J.; Hatton, T.A.; Bhatia, S.N. SERS-coded gold nanorods as a multifunctional platform for densely multiplexed near-infrared imaging and photothermal heating. Adv. Mater. 2009, 21,3175-3180. [CrossRef]

158. Wang, J.; Liang, D.; Jin, Q.; Feng, J.; Tang, X. Bioorthogonal SERS Nanotags as a Precision Theranostic Platform for in vivo SERS Imaging and Cancer Photothermal Therapy. Bioconjugate Chem. 2020, 31, 182-193. [CrossRef]

159. Vendrell, M.; Maiti, K.K.; Dhaliwal, K.; Chang, Y.-T. Surface-enhanced Raman scattering in cancer detection and imaging. Trends Biotechnol. 2013, 31, 249-257. [CrossRef] [PubMed]

160. Lim, D.-K.; Jeon, K.-S.; Hwang, J.-H.; Kim, H.; Kwon, S.; Suh, Y.D.; Nam, J.-M. Highly uniform and reproducible surface-enhanced Raman scattering from DNA-tailorable nanoparticles with 1-nm interior gap. Nat. Nanotechnol. 2011, 6, 452. [CrossRef] [PubMed]

161. Schlücker, S. SERS microscopy: Nanoparticle probes and biomedical applications. ChemPhysChem 2009, 10, 1344-1354. [CrossRef]

162. Bantz, K.C.; Meyer, A.F.; Wittenberg, N.J.; Im, H.; Kurtuluş, Ö.; Lee, S.H.; Lindquist, N.C.; Oh, S.-H.; Haynes, C.L. Recent progress in SERS biosensing. Phys. Chem. Chem. Phys. 2011, 13, 11551-11567. [CrossRef]

163. Kneipp, J.; Kneipp, H.; Wittig, B.; Kneipp, K. Novel optical nanosensors for probing and imaging live cells. Nanomed. Nanotechnol. Biol. Med. 2010, 6, 214-226. [CrossRef]

164. Chon, H.; Lee, S.; Yoon, S.-Y.; Chang, S.-I.; Lim, D.W.; Choo, J. Simultaneous immunoassay for the detection of two lung cancer markers using functionalized SERS nanoprobes. Chem. Commun. 2011, 47, 12515-12517. [CrossRef] 
165. Lee, M.; Lee, S.; Lee, J.; Lim, H.; Seong, G.H.; Lee, E.K.; Chang, S.-I.; Oh, C.H.; Choo, J. Highly reproducible immunoassay of cancer markers on a gold-patterned microarray chip using surface-enhanced Raman scattering imaging. Biosens. Bioelectron. 2011, 26, 2135-2141. [CrossRef] [PubMed]

166. Lu, W.; Singh, A.K.; Khan, S.A.; Senapati, D.; Yu, H.; Ray, P.C. Gold nano-popcorn-based targeted diagnosis, nanotherapy treatment, and in situ monitoring of photothermal therapy response of prostate cancer cells using surface-enhanced Raman spectroscopy. J. Am. Chem. Soc. 2010, 132, 18103-18114. [CrossRef]

167. Samanta, A.; Maiti, K.K.; Soh, K.-S.; Liao, X.; Vendrell, M.; Dinish, U.S.; Yun, S.-W.; Bhuvaneswari, R.; Kim, H.; Rautela, S. Ultrasensitive near-infrared Raman reporters for SERS-based in vivo cancer detection. Angew. Chem. Int. Ed. 2011, 50, 6089-6092. [CrossRef]

168. Lee, S.; Chon, H.; Lee, M.; Choo, J.; Shin, S.Y.; Lee, Y.H.; Son, S.W.; Oh, C.H. Surface-enhanced Raman scattering imaging of HER2 cancer markers overexpressed in single MCF7 cells using antibody conjugated hollow gold nanospheres. Biosens. Bioelectron. 2009, 24, 2260-2263. [CrossRef] [PubMed]

169. Ganesan, S.; Venkatakrishnan, K.; Tan, B. Wrinkled metal based quantum sensor for In vitro cancer diagnosis. Biosens. Bioelectron. 2020, 151, 111967. [CrossRef] [PubMed]

170. Austin, L.A.; Mackey, M.A.; Dreaden, E.C.; El-Sayed, M.A. The optical, photothermal, and facile surface chemical properties of gold and silver nanoparticles in biodiagnostics, therapy, and drug delivery. Arch. Toxicol. 2014, 88, 1391-1417. [CrossRef]

171. Kuo, W.-S.; Chang, C.-N.; Chang, Y.-T.; Yeh, C.-S. Antimicrobial gold nanorods with dual-modality photodynamic inactivation and hyperthermia. Chem. Commun. 2009, 4853-4855. [CrossRef]

172. Lin, J.; Wang, S.; Huang, P.; Wang, Z.; Chen, S.; Niu, G.; Li, W.; He, J.; Cui, D.; Lu, G. Photosensitizer-loaded gold vesicles with strong plasmonic coupling effect for imaging-guided photothermal/photodynamic therapy. ACS Nano 2013, 7, 5320-5329. [CrossRef]

173. Kolemen, S.; Ozdemir, T.; Lee, D.; Kim, G.M.; Karatas, T.; Yoon, J.; Akkaya, E.U. Remote-controlled release of singlet oxygen by the plasmonic heating of endoperoxide-modified gold nanorods: Towards a paradigm change in photodynamic therapy. Angew. Chem. Int. Ed. 2016, 55, 3606-3610. [CrossRef]

174. Cheng, G.; Li, B. Nanoparticle-based photodynamic therapy: New trends in wound healing applications. Mater. Today Adv. 2020, 6, 100049. [CrossRef]

175. Norouzi, H.; Khoshgard, K.; Akbarzadeh, F. In vitro outlook of gold nanoparticles in photo-thermal therapy: A literature review. Lasers Med. Sci. 2018, 33, 917-926. [CrossRef] [PubMed]

176. Belyanina, I.V.; Zamay, T.N.; Zamay, G.S.; Zamay, S.S.; Kolovskaya, O.S.; Ivanchenko, T.I.; Denisenko, V.V.; Kirichenko, A.K.; Glazyrin, Y.E.; Garanzha, I.V. In vivo cancer cells elimination guided by aptamer-functionalized gold-coated magnetic nanoparticles and controlled with low frequency alternating magnetic field. Theranostics 2017, 7, 3326. [CrossRef] [PubMed]

177. Li, Y.; Lin, T.; Luo, Y.; Liu, Q.; Xiao, W.; Guo, W.; Lac, D.; Zhang, H.; Feng, C.; Wachsmann-Hogiu, S. A smart and versatile theranostic nanomedicine platform based on nanoporphyrin. Nat. Commun. 2014, 5, 1-15. [CrossRef] [PubMed]

178. Link, S.; El-Sayed, M.A. Shape and size dependence of radiative, non-radiative and photothermal properties of gold nanocrystals. Int. Rev. Phys. Chem. 2000, 19, 409-453. [CrossRef]

179. Behnam, M.A.; Emami, F.; Sobhani, Z.; Koohi-Hosseinabadi, O.; Dehghanian, A.R.; Zebarjad, S.M.; Moghim, M.H.; Oryan, A. Novel combination of silver nanoparticles and carbon nanotubes for plasmonic photo thermal therapy in melanoma cancer model. Adv. Pharm. Bull. 2018, 8, 49. [CrossRef]

180. Lee, J.; Lee, Y.H.; Jeong, C.B.; Choi, J.S.; Chang, K.S.; Yoon, M. Gold nanorods-conjugated TiO 2 nanoclusters for the synergistic combination of phototherapeutic treatments of cancer cells. J. Nanobiotechnol. 2018, 16, 1-12. [CrossRef]

181. Pasparakis, G. Light-induced generation of singlet oxygen by naked gold nanoparticles and its implications to cancer cell phototherapy. Small 2013, 9, 4130-4134. [CrossRef]

182. Chen, H.-C.; Hwang, B.-J.; Mai, F.-D.; Liu, Y.-C.; Lin, C.-M.; Kuo, H.-S.; Chou, D.-S.; Lee, M.-J.; Yang, K.-H.; $\mathrm{Yu}, \mathrm{C}$.-C. Active and stable liquid water innovatively prepared using resonantly illuminated gold nanoparticles. ACS Nano 2014, 8, 2704-2713. [CrossRef]

183. Wang, C.-K.; Chen, H.-C.; Fang, S.-U.; Ho, C.-W.; Tai, C.-J.; Yang, C.-P.; Liu, Y.-C. Innovatively therapeutic strategy on lung cancer by daily drinking antioxidative plasmon-induced activated water. Sci. Rep. 2018, 8, 1-10. [CrossRef] 
184. Rajan, Y.C.; Inbaraj, B.S.; Chen, B.H. Synthesis and characterization of poly ( $\gamma$-glutamic acid)-based alumina nanoparticles with their protein adsorption efficiency and cytotoxicity towards human prostate cancer cells. RSC Adv. 2015, 5, 15126-15139. [CrossRef]

185. Burgdorf, S.; Kurts, C. Endocytosis mechanisms and the cell biology of antigen presentation. Curr. Opin. Immunol. 2008, 20, 89-95. [CrossRef]

186. Li, H.; Li, Y.; Jiao, J.; Hu, H.-M. Alpha-alumina nanoparticles induce efficient autophagy-dependent cross-presentation and potent antitumour response. Nat. Nanotechnol. 2011, 6, 645-650. [CrossRef]

187. Sun, Z.; Wang, W.; Wang, R.; Duan, J.; Hu, Y.; Ma, J.; Zhou, J.; Xie, S.; Lu, X.; Zhu, Z. Aluminum nanoparticles enhance anticancer immune response induced by tumor cell vaccine. Cancer Nanotechnol. 2010, 1, 63-69. [CrossRef]

188. Lin, W.; Stayton, I.; Huang, Y.; Zhou, X.-D.; Ma, Y. Cytotoxicity and cell membrane depolarization induced by aluminum oxide nanoparticles in human lung epithelial cells A549. Toxicol. Environ. Chem. 2008, 90, 983-996. [CrossRef]

189. Zhao, J.; Pan, N.; Huang, F.; Aldarouish, M.; Wen, Z.; Gao, R.; Zhang, Y.; Hu, H.-M.; Shen, Y.; Wang, L. Vx3-functionalized alumina nanoparticles assisted enrichment of ubiquitinated proteins from cancer cells for enhanced cancer immunotherapy. Bioconjug. Chem. 2018, 29, 786-794. [CrossRef]

190. Jain, A.; Koyani, R.; Muñoz, C.; Sengar, P.; Contreras, O.E.; Juárez, P.; Hirata, G.A. Magnetic-luminescent cerium-doped gadolinium aluminum garnet nanoparticles for simultaneous imaging and photodynamic therapy of cancer cells. J. Colloid Interface Sci. 2018, 526, 220-229. [CrossRef]

191. Ashton, L.; Lau, K.; Winder, C.L.; Goodacre, R. Raman spectroscopy: Lighting up the future of microbial identification. Future Microbiol. 2011, 6, 991-997. [CrossRef]

192. Van Loosdrecht, M.C.M.; Eikelboom, D.; Gjaltema, A.; Mulder, A.; Tijhuis, L.; Heijnen, J.J. Biofilm structures. Water Sci. Technol. 1995, 32, 35. [CrossRef]

193. Khatoon, Z.; McTiernan, C.D.; Suuronen, E.J.; Mah, T.-F.; Alarcon, E.I. Bacterial biofilm formation on implantable devices and approaches to its treatment and prevention. Heliyon 2018, 4, e01067. [CrossRef]

194. Bjarnsholt, T. The role of bacterial biofilms in chronic infections. Apmis 2013, 121, 1-58. [CrossRef]

195. Flemming, H.-C.; Wingender, J. The biofilm matrix. Nat. Rev. Microbiol. 2010, 8, 623-633. [CrossRef]

196. Rautemaa, R.; Ramage, G. Oral candidosis-clinical challenges of a biofilm disease. Crit. Rev. Microbiol. 2011, 37, 328-336. [CrossRef]

197. Davies, D. Understanding biofilm resistance to antibacterial agents. Nat. Rev. Drug Discov. 2003, 2, 114-122. [CrossRef]

198. Mah, T.-F.C.; O'Toole, G.A. Mechanisms of biofilm resistance to antimicrobial agents. Trends Microbiol. 2001, 9, 34-39. [CrossRef]

199. Hall-Stoodley, L.; Costerton, J.W.; Stoodley, P. Bacterial biofilms: From the natural environment to infectious diseases. Nat. Rev. Microbiol. 2004, 2, 95-108. [CrossRef]

200. Mi, G.; Shi, D.; Wang, M.; Webster, T.J. Reducing bacterial infections and biofilm formation using nanoparticles and nanostructured antibacterial surfaces. Adv. Healthc. Mater. 2018, 7, 1800103. [CrossRef]

201. Deng, H.; McShan, D.; Zhang, Y.; Sinha, S.S.; Arslan, Z.; Ray, P.C.; Yu, H. Mechanistic study of the synergistic antibacterial activity of combined silver nanoparticles and common antibiotics. Environ. Sci. Technol. 2016, 50, 8840-8848. [CrossRef]

202. Fayaz, A.M.; Balaji, K.; Girilal, M.; Yadav, R.; Kalaichelvan, P.T.; Venketesan, R. Biogenic synthesis of silver nanoparticles and their synergistic effect with antibiotics: A study against gram-positive and gram-negative bacteria. Nanomed. Nanotechnol. Biol. Med. 2010, 6, 103-109. [CrossRef]

203. Panáček, A.; Kvítek, L.; Smékalová, M.; Večeřová, R.; Kolář, M.; Röderová, M.; Dyčka, F.; Šebela, M.; Prucek, R.; Tomanec, O. Bacterial resistance to silver nanoparticles and how to overcome it. Nat. Nanotechnol. 2018, 13, 65-71. [CrossRef]

204. Jones, O.; Preston, M.R.; Fawell, J.; Mayes, W.; Cartmell, E.; Pollard, S.; Harrison, R.M.; Mackenzie, A.R.; Williams, M.; Maynard, R. Pollution: Causes, Effects and Control; Royal Society of Chemistry: Cambridge, UK, 2015.

205. White, R. Silver in healthcare: Its antimicrobial efficacy and safety in use. J. Wound Care 2011, 20, 26. [CrossRef]

206. Leitz, M.; Tamachkiarow, A.; Franke, H.; Grattan, K.T.V. Monitoring of biofilm growth using ATR-leaky mode spectroscopy. J. Phys. D Appl. Phys. 2001, 35, 55. [CrossRef] 
207. Leitz, M.; Franke, H. Observation of low aluminum corrosion rates during biofilm formation. In Proceedings of the Optical Fibers and Sensors for Medical Applications II International Society for Optics and Photonics, San Jose, CA, USA, 26 March 2002; Volume 4616, pp. 229-236.

208. Dou, X.; Chung, P.-Y.; Jiang, P.; Dai, J. Surface plasmon resonance-enabled antibacterial digital versatile discs. Appl. Phys. Lett. 2012, 100, 063702. [CrossRef]

209. Zhou, H.; Yang, D.; Ivleva, N.P.; Mircescu, N.E.; Schubert, S.; Niessner, R.; Wieser, A.; Haisch, C. Label-free in situ discrimination of live and dead bacteria by surface-enhanced Raman scattering. Anal. Chem. 2015, 87, 6553-6561. [CrossRef]

210. West, P.R.; Ishii, S.; Naik, G.V.; Emani, N.K.; Shalaev, V.M.; Boltasseva, A. Searching for better plasmonic materials. Laser Photonics Rev. 2010, 4, 795-808. [CrossRef]

211. Cortie, M.B.; McDonagh, A.M. Synthesis and optical properties of hybrid and alloy plasmonic nanoparticles. Chem. Rev. 2011, 111, 3713-3735. [CrossRef] [PubMed]

212. Gong, C.; Leite, M.S. Noble metal alloys for plasmonics. ACS Photonics 2016, 3, 507-513. [CrossRef]

213. Blaber, M.G.; Arnold, M.D.; Ford, M.J. A review of the optical properties of alloys and intermetallics for plasmonics. J. Phys. Condens. Matter 2010, 22, 143201. [CrossRef]

214. De Silva, K.S.B.; Keast, V.J.; Cortie, M.B. Effect of Al additions on the optical properties of Au $\alpha$-phase. J. Alloy. Compd. 2016, 679, 225-230. [CrossRef]

215. Shahcheraghi, N.; Keast, V.J.; Gentle, A.R.; Arnold, M.D.; Cortie, M.B. Anomalously strong plasmon resonances in aluminium bronze by modification of the electronic density-of-states. J. Phys. Condens. Matter 2016, 28, 405501. [CrossRef]

216. Withers, Z.H.; Voronine, D.V. Quantum Medicine with Ultraviolet Aluminum Nanolasers. IEEE J. Sel. Top. Quantum Electron. 2018, 25, 1-6. [CrossRef]

217. Auer, S.; Wan, W.; Huang, X.; Ramirez, A.G.; Cao, H. Morphology-induced plasmonic resonances in silver-aluminum alloy thin films. Appl. Phys. Lett. 2011, 99, 041116. [CrossRef]

218. Parashar, P.K.; Komarala, V.K. Engineered optical properties of silver-aluminum alloy nanoparticles embedded in SiON matrix for maximizing light confinement in plasmonic silicon solar cells. Sci. Rep. 2017, 7, 1-9. [CrossRef]

219. De Silva, K.S.; Keast, V.J.; Gentle, A.; Cortie, M.B. Optical properties and oxidation of $\alpha$-phase Ag-Al thin films. Nanotechnology 2017, 28, 095202. [CrossRef]

220. Gu, D.; Zhang, C.; Wu, Y.-K.; Guo, L.J. Ultrasmooth and thermally stable silver-based thin films with subnanometer roughness by aluminum doping. ACS Nano 2014, 8, 10343-10351. [CrossRef] [PubMed]

221. Kim, J.-Y.; Na, S.-I.; Ha, G.-Y.; Kwon, M.-K.; Park, I.-K.; Lim, J.-H.; Park, S.-J.; Kim, M.-H.; Choi, D.; Min, K. Thermally stable and highly reflective AgAl alloy for enhancing light extraction efficiency in GaN light-emitting diodes. Appl. Phys. Lett. 2006, 88, 043507. [CrossRef]

222. Ali, M.K.M.; Ibrahim, K.; Mkawi, E.M. Ag-Al alloy thin film on plastic substrate by screen printing for solar cell back contact application. Mater. Sci. Semicond. Process. 2013, 16, 593-597. [CrossRef]

223. Zhang, C.; Zhao, D.; Gu, D.; Kim, H.; Ling, T.; Wu, Y.-K.R.; Guo, L.J. An ultrathin, smooth, and low-loss Al-doped Ag film and its application as a transparent electrode in organic photovoltaics. Adv. Mater. 2014, 26, 5696-5701. [CrossRef] [PubMed]

224. Kuiri, P.K. Tailoring localized surface plasmons in Ag-Al alloys' nanoparticles. J. Alloy. Compd. 2020, 826, 154250. [CrossRef]

225. Chowdhury, M.H.; Chakraborty, S.; Lakowicz, J.R.; Ray, K. Feasibility of using bimetallic plasmonic nanostructures to enhance the intrinsic emission of biomolecules. J. Phys. Chem. C 2011, 115, 16879-16891. [CrossRef]

226. Otto, A. The 'chemical' (electronic) contribution to surface-enhanced Raman scattering. J. Raman Spectrosc. 2005, 36, 497-509. [CrossRef]

227. Lombardi, J.R.; Birke, R.L. A unified view of surface-enhanced Raman scattering. Acc. Chem. Res. 2009, 42, 734-742. [CrossRef]

228. Moskovits, M. Persistent misconceptions regarding SERS. Phys. Chem. Chem. Phys. 2013, 15, 5301-5311. [CrossRef]

229. Sun, M.; Liu, S.; Li, Z.; Duan, J.; Chen, M.; Xu, H. Direct visual evidence for the chemical mechanism of surface-enhanced resonance Raman scattering via charge transfer:(II) Binding-site and quantum-size effects. J. Raman Spectrosc. 2009, 40, 1172-1177. [CrossRef] 
230. Zhao, L.; Jensen, L.; Schatz, G.C. Pyridine- Ag20 Cluster: A model system for studying surface-enhanced Raman scattering. J. Am. Chem. Soc. 2006, 128, 2911-2919. [CrossRef] [PubMed]

231. Mokkath, J.H. Competing plasmonic and charge-transfer excitations in pyridine adsorbed silver and aluminum nanoparticles. Phys. Chem. Chem. Phys. 2018, 20, 15884-15889. [CrossRef]

232. Bergman, D.J.; Stockman, M.I. Surface plasmon amplification by stimulated emission of radiation: Quantum generation of coherent surface plasmons in nanosystems. Phys. Rev. Lett. 2003, 90, 027402. [CrossRef] [PubMed]

233. Stockman, M.I. Spasers explained. Nat. Photonics 2008, 2, 327-329. [CrossRef]

234. Noginov, M.A.; Zhu, G.; Belgrave, A.M.; Bakker, R.; Shalaev, V.M.; Narimanov, E.E.; Stout, S.; Herz, E.; Suteewong, T.; Wiesner, U. Demonstration of a spaser-based nanolaser. Nature 2009, 460, 1110-1112. [CrossRef]

235. Galanzha, E.I.; Weingold, R.; Nedosekin, D.A.; Sarimollaoglu, M.; Nolan, J.; Harrington, W.; Kuchyanov, A.S.; Parkhomenko, R.G.; Watanabe, F.; Nima, Z. Spaser as a biological probe. Nat. Commun. 2017, 8, 15528. [CrossRef] [PubMed]

236. Chou, B.-T.; Chou, Y.-H.; Wu, Y.-M.; Chung, Y.-C.; Hsueh, W.-J.; Lin, S.-W.; Lu, T.-C.; Lin, T.-R.; Lin, S.-D. Single-crystalline aluminum film for ultraviolet plasmonic nanolasers. Sci. Rep. 2016, 6, 19887. [CrossRef] [PubMed]

237. Zhang, Q.; Li, G.; Liu, X.; Qian, F.; Li, Y.; Sum, T.C.; Lieber, C.M.; Xiong, Q. A room temperature low-threshold ultraviolet plasmonic nanolaser. Nat. Commun. 2014, 5, 1-9. [CrossRef] [PubMed]

238. Chou, Y.-H.; Wu, Y.-M.; Hong, K.-B.; Chou, B.-T.; Shih, J.-H.; Chung, Y.-C.; Chen, P.-Y.; Lin, T.-R.; Lin, C.-C.; Lin, S.-D. High-operation-temperature plasmonic nanolasers on single-crystalline aluminum. Nano Lett. 2016, 16, 3179-3186. [CrossRef] [PubMed]

239. Chou, Y.-H.; Hong, K.-B.; Chung, Y.-C.; Chang, C.-T.; Chou, B.-T.; Lin, T.-R.; Arakelian, S.M.; Alodjants, A.P.; Lu, T.-C. Metal for plasmonic ultraviolet laser: Al or Ag? IEEE J. Sel. Top. Quantum Electron. 2017, 23, 1-7. [CrossRef]

240. Dorfman, K.E.; Jha, P.K.; Voronine, D.V.; Genevet, P.; Capasso, F.; Scully, M.O. Quantum-coherence-enhanced surface plasmon amplification by stimulated emission of radiation. Phys. Rev. Lett. 2013, 111, 043601. [CrossRef] [PubMed]

241. Tuchscherer, P.; Rewitz, C.; Voronine, D.V.; de Abajo, F.J.G.; Pfeiffer, W.; Brixner, T. Analytic coherent control of plasmon propagation in nanostructures. Opt. Express 2009, 17, 14235-14259. [CrossRef] [PubMed]

242. Huo, W.; Voronine, D.V.; Scully, M. Generation and quantum control of giant plasmon pulses by transient quantum coherence. Phys. Rev. A 2015, 91, 043844. [CrossRef]

243. Voronine, D.V.; Huo, W.; Scully, M. Ultrafast dynamics of surface plasmon nanolasers with quantum coherence and external plasmonic feedback. J. Opt. 2014, 16, 114013. [CrossRef]

244. Schubert, P.; Johnson, L.; Marks, D.C.; Devine, D.V. Ultraviolet-based pathogen inactivation systems: Untangling the molecular targets activated in platelets. Front. Med. 2018, 5, 129. [CrossRef]

245. Fryk, J.J.; Marks, D.C.; Hobson-Peters, J.; Watterson, D.; Hall, R.A.; Young, P.R.; Reichenberg, S.; Tolksdorf, F.; Sumian, C.; Gravemann, U. Reduction of Zika virus infectivity in platelet concentrates after treatment with ultraviolet $C$ light and in plasma after treatment with methylene blue and visible light. Transfusion 2017, 57, 2677-2682. [CrossRef]

246. Santa Maria, F.; Laughhunn, A.; Lanteri, M.C.; Aubry, M.; Musso, D.; Stassinopoulos, A. Inactivation of Zika virus in platelet components using amotosalen and ultraviolet A illumination. Transfusion 2017, 57, 2016-2025. [CrossRef]

247. Faddy, H.M.; Fryk, J.J.; Watterson, D.; Young, P.R.; Modhiran, N.; Muller, D.A.; Keil, S.D.; Goodrich, R.P.; Marks, D.C. Riboflavin and ultraviolet light: Impact on dengue virus infectivity. Vox Sang. 2016, 111, $235-241$. [CrossRef]

248. Owada, T.; Kaneko, M.; Matsumoto, C.; Sobata, R.; Igarashi, M.; Suzuki, K.; Matsubayashi, K.; Mio, K.; Uchida, S.; Satake, M. Establishment of culture systems for G enotypes 3 and 4 hepatitis E virus (HEV) obtained from human blood and application of HEV inactivation using a pathogen reduction technology system. Transfusion 2014, 54, 2820-2827. [CrossRef]

249. Kwon, S.-Y.; Kim, I.S.; Bae, J.E.; Kang, J.W.; Cho, Y.J.; Cho, N.S.; Lee, S.W. Pathogen inactivation efficacy of Mirasol PRT System and Intercept Blood System for non-leucoreduced platelet-rich plasma-derived platelets suspended in plasma. Vox Sang. 2014, 107, 254-260. [CrossRef] 
250. Girard, Y.A.; Santa Maria, F.; Lanteri, M.C. Inactivation of yellow fever virus with amotosalen and ultraviolet A light pathogen-reduction technology. Transfusion 2020, 60, 622-627. [CrossRef] [PubMed]

251. Aubry, M.; Richard, V.; Green, J.; Broult, J.; Musso, D. Inactivation of Z ika virus in plasma with amotosalen and ultraviolet a illumination. Transfusion 2016, 56, 33-40. [CrossRef]

252. Lamont, Y.; Rzeżutka, A.; Anderson, J.G.; MacGregor, S.J.; Given, M.J.; Deppe, C.; Cook, N. Pulsed UV-light inactivation of poliovirus and adenovirus. Lett. Appl. Microbiol. 2007, 45, 564-567. [CrossRef] [PubMed]

253. Lizasoain, A.; Tort, L.F.L.; García, M.; Gillman, L.; Alberti, A.; Leite, J.P.G.; Miagostovich, M.P.; Pou, S.A.; Cagiao, A.; Razsap, A. Human enteric viruses in a wastewater treatment plant: Evaluation of activated sludge combined with UV disinfection process reveals different removal performances for viruses with different features. Lett. Appl. Microbiol. 2018, 66, 215-221. [CrossRef] [PubMed]

254. Chevrefils, G.; Caron, É.; Wright, H.; Sakamoto, G.; Payment, P.; Barbeau, B.; Cairns, B. UV dose required to achieve incremental log inactivation of bacteria, protozoa and viruses. IUVA News 2006, 8, 38-45.

255. Lytle, C.D.; Sagripanti, J.-L. Predicted inactivation of viruses of relevance to biodefense by solar radiation. J. Virol. 2005, 79, 14244-14252. [CrossRef]

256. Heaselgrave, W.; Patel, N.; Kilvington, S.; Kehoe, S.C.; McGuigan, K.G. Solar disinfection of poliovirus and Acanthamoeba polyphaga cysts in water-a laboratory study using simulated sunlight. Lett. Appl. Microbiol. 2006, 43, 125-130. [CrossRef]

257. Rueckert, R.R. The viruses and their replication. Fields Virol. 1996, 609-654.

258. Heaselgrave, W.; Kilvington, S. The efficacy of simulated solar disinfection (SODIS) against Ascaris, Giardia, Acanthamoeba, Naegleria, Entamoeba and Cryptosporidium. Acta Trop. 2011, 119, 138-143. [CrossRef]

259. Gerba, C.P.; Gramos, D.M.; Nwachuku, N. Comparative inactivation of enteroviruses and adenovirus 2 by UV light. Appl. Environ. Microbiol. 2002, 68, 5167-5169. [CrossRef]

260. Nims, R.; Plavsic, M. Inactivation of caliciviruses. Pharmaceuticals 2013, 6, 358-392. [CrossRef] [PubMed]

261. Wigginton, K.R.; Menin, L.; Sigstam, T.; Gannon, G.; Cascella, M.; Hamidane, H.B.; Tsybin, Y.O.; Waridel, P.; Kohn, T. UV Radiation Induces Genome-Mediated, Site-Specific Cleavage in Viral Proteins. ChemBioChem 2012, 13, 837-845. [CrossRef]

262. Eischeid, A.C.; Meyer, J.N.; Linden, K.G. UV disinfection of adenoviruses: Molecular indications of DNA damage efficiency. Appl. Environ. Microbiol. 2009, 75, 23-28. [CrossRef]

263. Fumian, T.M.; Guimarães, F.R.; Pereira Vaz, B.J.; da Silva, M.T.T.; Muylaert, F.F.; Bofill-Mas, S.; Gironés, R.; Leite, J.P.G.; Miagostovich, M.P. Molecular detection, quantification and characterization of human polyomavirus JC from waste water in Rio De Janeiro, Brazil. J. Water Health 2010, 8, 438-445. [CrossRef] [PubMed]

264. Nuanualsuwan, S.; Cliver, D.O. Capsid functions of inactivated human picornaviruses and feline calicivirus. Appl. Environ. Microbiol. 2003, 69, 350-357. [CrossRef] [PubMed]

265. Jumat, M.R.; Hong, P.-Y. Inactivation and Loss of Infectivity of Enterovirus 70 by Solar Irradiation. Water 2019, 11, 64. [CrossRef]

266. Woo, H.; Beck, S.E.; Boczek, L.A.; Carlson, K.M.; Brinkman, N.E.; Linden, K.G.; Lawal, O.R.; Hayes, S.L.; Ryu, H. Efficacy of Inactivation of Human Enteroviruses by Dual-Wavelength Germicidal Ultraviolet (UV-C) Light Emitting Diodes (LEDs). Water 2019, 11, 1131. [CrossRef]

267. Greninger, A.L.; Naccache, S.N.; Messacar, K.; Clayton, A.; Yu, G.; Somasekar, S.; Federman, S.; Stryke, D.; Anderson, C.; Yagi, S. A novel outbreak enterovirus D68 strain associated with acute flaccid myelitis cases in the USA (2012-14): A retrospective cohort study. Lancet Infect. Dis. 2015, 15, 671-682. [CrossRef]

268. Khan, F. Enterovirus D68: Acute respiratory illness and the 2014 outbreak. Emerg. Med. Clin. 2015, 33, e19-e32. [CrossRef]

269. Leifels, M.; Jurzik, L.; Wilhelm, M.; Hamza, I.A. Use of ethidium monoazide and propidium monoazide to determine viral infectivity upon inactivation by heat, UV-exposure and chlorine. Int. J. Hyg. Environ. Health 2015, 218, 686-693. [CrossRef]

270. Ko, G.; Cromeans, T.L.; Sobsey, M.D. UV inactivation of adenovirus type 41 measured by cell culture mRNA RT-PCR. Water Res. 2005, 39, 3643-3649. [CrossRef] [PubMed]

271. Sangsanont, J.; Katayama, H.; Kurisu, F.; Furumai, H. Capsid-damaging effects of UV irradiation as measured by quantitative PCR coupled with ethidium monoazide treatment. Food Environ. Virol. 2014, 6, 269-275. [CrossRef] [PubMed] 
272. Baxter, C.S.; Hofmann, R.; Templeton, M.R.; Brown, M.; Andrews, R.C. Inactivation of adenovirus types 2, 5 , and 41 in drinking water by UV light, free chlorine, and monochloramine. J. Environ. Eng. 2007, 133, 95-103. [CrossRef]

273. Tanaka, T.; Nogariya, O.; Shionoiri, N.; Maeda, Y.; Arakaki, A. Integrated molecular analysis of the inactivation of a non-enveloped virus, feline calicivirus, by UV-C radiation. J. Biosci. Bioeng. 2018, 126, 63-68. [CrossRef] [PubMed]

274. Lipsitch, M.; Swerdlow, D.L.; Finelli, L. Defining the epidemiology of Covid-19—Studies needed. N. Engl. J. Med. 2020, 382, 1194-1196. [CrossRef]

275. World Health Organization. Naming the Coronavirus Disease (COVID-19) and the Virus That Causes It. 2020. Available online: https:/www.who.int/emergencies/diseases/novel-coronavirus-2019/technical-guidance/ naming-the-coronavirus-disease-(covid-2019)-and-the-virus-that-causes-it (accessed on 1 June 2020).

276. Dietz, L.; Horve, P.F.; Coil, D.; Fretz, M.; Van Den Wymelenberg, K. 2019 novel coronavirus (COVID-19) pandemic: Built environment considerations to reduce transmission. mSystems 2020, 5, e00245-20. [CrossRef]

277. Mills, D.; Harnish, D.A.; Lawrence, C.; Sandoval-Powers, M.; Heimbuch, B.K. Ultraviolet germicidal irradiation of influenza-contaminated N95 filtering facepiece respirators. Am. J. Infect. Control 2018, 46, e49-e55. [CrossRef]

278. Lindsley, W.G.; Martin, S.B., Jr.; Thewlis, R.E.; Sarkisian, K.; Nwoko, J.O.; Mead, K.R.; Noti, J.D. Effects of ultraviolet germicidal irradiation (UVGI) on N95 respirator filtration performance and structural integrity. J. Occup. Environ. Hyg. 2015, 12, 509-517. [CrossRef]

279. Viscusi, D.J.; Bergman, M.S.; Eimer, B.C.; Shaffer, R.E. Evaluation of five decontamination methods for filtering facepiece respirators. Ann. Occup. Hyg. 2009, 53, 815-827.

280. Farrokhian, V.G.; Ho, E.; King, E.S.; Krishnan, N.; Kuzmin, G.; Maltas, J.; Pelesko, J.; Scarborough, J.A.; Scott, J.G.; Sedor, G. UV Sterilization of Personal Protective Equipment with Idle Laboratory Biosafety Cabinets During the COVID-19 Pandemic. medRxiv 2020. [CrossRef]

281. Lowe, J.J.; Paladino, K.D.; Farke, J.D.; Boulter, K.; Cawcutt, K.; Emodi, M.; Gibbs, S.; Hankins, R.; Hinkle, L.; Micheels, T. N95 Filtering Facemask Receptor Ultraviolet Germicidal Irradiation (UVGI) Process for Decontamination and Reuse; Technical Report; Nebraska Medicine: Omaha, NE, USA, 2020.

282. She, R.C.; Chen, D.; Pak, P.; Armani, D.K.; Schubert, A.; Armani, A.M. Build-at-home UV-C disinfection system for healthcare settings. arXiv 2003, arXiv:2003.12916.

283. Pratelli, A. Canine coronavirus inactivation with physical and chemical agents. Vet. J. 2008, 177, 71-79. [CrossRef] [PubMed]

284. Duan, S.M.; Zhao, X.S.; Wen, R.F.; Huang, J.; Pi, G.H.; Zhang, S.X.; Han, J.; Bi, S.L.; Ruan, L.; Dong, X. Stability of SARS coronavirus in human specimens and environment and its sensitivity to heating and UV irradiation. Biomed. Environ. Sci. BES 2003, 16, 246-255. [PubMed]

285. Darnell, M.E.; Subbarao, K.; Feinstone, S.M.; Taylor, D.R. Inactivation of the coronavirus that induces severe acute respiratory syndrome, SARS-CoV. J. Virol. Methods 2004, 121, 85-91. [CrossRef] [PubMed]

(C) 2020 by the authors. Licensee MDPI, Basel, Switzerland. This article is an open access article distributed under the terms and conditions of the Creative Commons Attribution (CC BY) license (http://creativecommons.org/licenses/by/4.0/). 